\title{
Transition Relief for Tax Reform's Third Rail: Reforming the Home Mortgage Interest Deduction After the Housing Market Crash
}

\author{
NICHOLAUS W. NORVELL*
}

TABLE OF CONTENTS

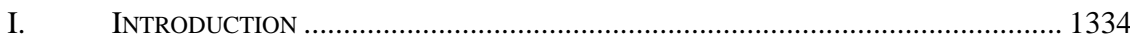

II. BACKGROUND ON THE MoRTGAGE INTEREST DEDUCTION.................................... 1337

A. How the Deduction Works .................................................................... 1337

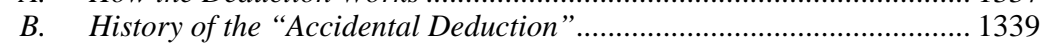

C. Intended Benefits: Achieving the American Dream ............................... 1341

III. Mortgage InTEREST Deduction Downsides AND

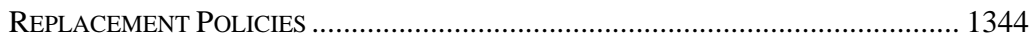

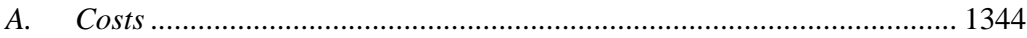

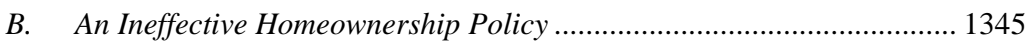

C. A Regressive Provision with Harmful Side Effects................................. 1346

D. Is Homeownership Worth Subsidizing? .................................................. 1349

E. Three Options for the Treatment of Mortgage Interest in

Comprehensive Tax Reform ................................................................. 1350

F. Implications of Changing the Mortgage Interest Deduction..................... 1352

1. Long-Term Considerations ........................................................ 1352

2. Short-Term Considerations............................................................... 1353

IV. OPTIONS FOR REFORMING THE DEDUCTION IN A FRAGILE

HOUSING MARKET ........................................................................................ 1355

* J.D. Candidate, University of San Diego School of Law, 2013; B.A., Government, Wesleyan University, 2007. I thank Professor Jordan Barry for his thoughtful guidance as my faculty adviser, as well as the San Diego Law Review staff for their diligent editorial work. I am also very grateful for the support of my family. I dedicate this Comment to Adam, with whom I look forward to making a house a home. 
A. Option 1: Eliminate the Deduction ........................................................ 1355

1. Long-Term Advantages and Disadvantages ....................................... 1355

2. Short-Term Consequences ............................................................... 1359

3. Appropriate Transition Relief........................................................... 1361

B. $\quad$ Option 2: Replace the Deduction with a Tax Credit ............................. 1366

1. Long-Term Advantages and Disadvantages .................................. 1366

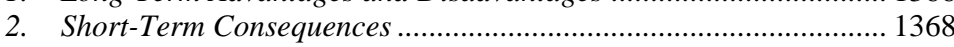

3. Appropriate Transition Relief ...................................................... 1368

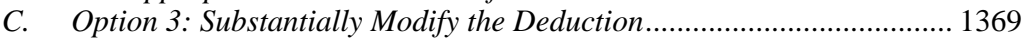

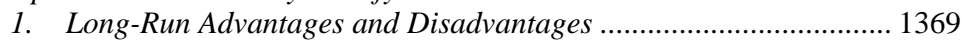

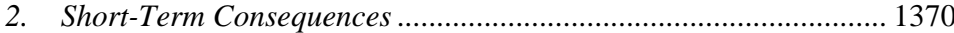

3. Appropriate Transition Relief........................................................... 1371

V. Conclusion: Congress Should Phase Out the Mortgage

INTEREST DEDUCTION THROUGH TAX REFORM.............................................. 1371

\section{INTRODUCTION}

The home mortgage interest deduction, "America's favorite tax break," should come to a necessary and deserved end in any comprehensive tax reform package Congress adopts. ${ }^{2}$ With fundamental tax reform touted as a vehicle for increasing economic competitiveness, lowering tax rates, closing part of the federal budget deficit, and making tax compliance simpler, ${ }^{3}$ members of both major political parties are scrutinizing costly

1. Jeanne Sahadi, Mortgage Deduction: America's Costliest Tax Break, CNN MoNEY (Apr. 15, 2010, 4:11 AM), http://money.cnn.com/2010/04/14/pf/taxes/mortgage interest_deduction/index.htm. An early 2012 poll commissioned by the National Association of Home Builders found that $73 \%$ of likely voters support keeping the deduction in the tax code. Alan Zibel, Poll: Don't Tread on My Mortgage-Interest Deduction, Wall St. J. Dev. Blog (Jan. 11, 2012, 6:34 PM), http://blogs.wsj.com/ developments/2012/01/11/poll-dont-tread-on-my-mortgage-interest-deduction. That being said, other polls show Americans may be willing to forgo many tax deductions, including the mortgage interest deduction, if the result would be substantially lower tax rates. See Ben Steverman, A Taxing Debate: The Mortgage-Interest Deduction, BlOOMBERG (Oct. 18, 2011, 8:13 AM), http://www.bloomberg.com/news/2011-10-17/a-taxing-debate-themortgage-interest-deduction.html.

2. See infra Part III. For a brief discussion of how bad provisions make their way into the tax code and rarely ever go away, see BERNARD SALANIÉ, THE ECONOMICS OF TAXATION 156-57 (1st ed. 2003) (explaining that legislators have an incentive to make tax burdens and benefits so hard for the public to understand that populist opposition to the tax system cannot emerge).

3. See Michael J. Graetz, 100 Million UnNeCEssary Returns: A Simple, Fair, AND COMPETITIVE TAX PLAN FOR THE UNITED STATES 3 (2008) (“[T]he minimal requirement for a tax system should be that it raises sufficient revenue to pay for government expenditures. A good tax system ought to do so fairly, keeping its costs of compliance and administration as low as feasible. It ought to be conducive to economic growth. Finally, it ought to ... interfer[e] minimally with private decision making. Our nation's tax system fails on every count.”). 
tax carve-outs like the mortgage interest deduction. ${ }^{4}$ The deduction makes a compelling target. Tax policy experts on both the left and right agree that the mortgage interest deduction fails to meaningfully increase the homeownership rate despite the substantial subsidy for many homeowners. ${ }^{5}$

Rather than helping renters on the cusp of ownership purchase a home, ${ }^{6}$ the mortgage interest deduction merely subsidizes those who would likely buy homes without a subsidy. ${ }^{7}$ These large subsidies for only a portion of homeowners carry harmful secondary social and economic effects. ${ }^{8}$ Homeowners with the deduction, for instance, can purchase larger, more expensive homes than they would otherwise. ${ }^{9}$ And where housing stock is limited, that subsidized demand drives housing inflation and actually reduces homeownership rates among almost all socioeconomic groups. $^{10}$ The inducement to purchase larger homes on larger lots also spurs overdevelopment of traffic-causing, open-space-razing suburban sprawl. $^{11}$

4. See Steverman, supra note 1 . In July 2011, the Republican Chairman of the House Ways and Means Committee, Representative Dave Camp, and the Democratic Chairman of the Senate Finance Committee, Senator Max Baucus, held a joint hearing on the tax treatment of debt and equity. For the announcement and witness statements, see Tax Reform and the Tax Treatment of Debt and Equity: J. Hearing Before the H. Comm. on Ways and Means \& S. Comm. on Fin., 112th Cong. (2011) (publication forthcoming), available at http://waysandmeans.house.gov/Calendar/EventSingle.aspx? EventID=250212. Leaders in both parties, however, remain purposely vague on tax reform details and how they would address politically difficult provisions like the mortgage interest deduction. See G.I., The Devil's in the Details (and the Politics), ECONOMIST FREE EXCHANGE BLOG (Feb. 22, 2012, 9:46 PM), http://www.economist.com /blogs/freeexchange/2012/02/tax-reform?page=3.

5. See Robert C. Pozen, The Mortgage Interest Deduction Needs To Be Slashed, BROOKINGS Institution (Mar. 28, 2011), http://www.brookings.edu/opinions/2011/0328 _mortgage_interest_deduction_pozen.aspx; Jonathan Williams, The Battle of the Home Mortgage Interest Deduction, TAX Found. TAX POL’y BlOG (Oct. 17, 2005), http:// taxfoundation.org/blog/battle-home-mortgage-interest-deduction; see also Zibel, supra note 1 (indicating "most economists" see the mortgage interest deduction as wasteful spending through the tax code).

6. See Edward L. Glaeser \& Jesse M. Shapiro, The Benefits of the Home Mortgage Interest Deduction, 17 TAX POL'y \& ECON. 37, 40 (2003).

7. Roberta F. Mann, The (Not So) Little House on the Prairie: The Hidden Costs of the Home Mortgage Interest Deduction, 32 ARIz. ST. L.J. 1347, 1361-62 (2000).

8. See id. at 1384; Christian A. L. Hilber \& Tracy M. Turner, The Mortgage Interest Deduction and Its Impact on Homeownership Decisions 22 (Spatial Econ. Research Ctr., Discussion Paper 55, 2010), available at http://eprints.lse.ac.uk/31759/1/ sercdp0055.pdf.

9. See infra text accompanying notes 90-95.

10. Hilber \& Turner, supra note 8, at 22.

11. Mann, supra note 7, at 1384. 
In spite of the mortgage interest deduction's shortcomings, congressional policymakers are understandably reluctant to reform it. ${ }^{12}$ Beyond anxiety about changing a popular tax break, Congress must also worry that reforming the deduction will affect the already-battered housing market, ${ }^{13}$ as well as homeowners who rely on the deduction each year. ${ }^{14}$ Those considerations should not, however, stop Congress from reforming the mortgage interest deduction. Rather, Congress should use tax reform as an opportunity to set the housing market on a more sustainable long-term path and prevent the next housing crisis, in part by reforming the mortgage interest deduction. ${ }^{15}$ This future benefit need not result in immediate pain; Congress can reform the mortgage interest deduction and protect the short-term housing market by adopting appropriate transition relief. ${ }^{16}$

This Comment argues that Congress should-in this order of preference-eliminate the mortgage interest deduction, replace it with a credit, or substantially modify it, and that Congress can adopt any of these policies without substantial short-term fallout in the housing

12. For example, Senators Ron Wyden and Dan Coats's bipartisan tax reform bill, which is explicitly aimed at eliminating a slew of deductions and lowering tax rates, retains the itemized deduction for mortgage interest. See Bipartisan Tax Fairness and Simplification Act of 2011, S. 727, 112th Cong. § 2(1)(B) (2011). Why? Perhaps because of the popular view that any lawmaker's attempt to eliminate the mortgage interest deduction would be “political suicide.” Paul Sullivan, Despite Critics, Mortgage Deduction Resists Change, N.Y. TIMES, Nov. 9, 2011, at F4.

13. In early 2012, property values were at a postbubble low, with the average home price one-third lower than what it was in 2006. Press Release, Fiserv, Inc., Fiserv Case-Shiller Home Price Insights: Home Prices Reach New Low, but Stabilization and Recovery Are in Sight (Jan. 30, 2012), http://investors.fiserv.com/releasedetail.cfm? ReleaseID $=643558$. Despite decreases in the foreclosure rate from the previous year and previous quarter, foreclosure starts in the second quarter of 2012 were at $0.96 \%$, near double the long-term average of $0.5 \%$, while the percentage of loans in foreclosure was $4.27 \%$, near the postbubble high and far from the long-term average of about $1.2 \%$. Press Release, Mortg. Bankers Ass'n, Mortgage Delinquencies Increase in Latest MBA Survey (Aug. 9, 2012), http://www.mbaa.org/NewsandMedia/PressCenter/81589.htm; Press Release, Mortg. Bankers Ass'n, Delinquencies and Foreclosures Decline in Latest MBA Mortgage Delinquency Survey (Feb. 16, 2012), http://www.mortgagebankers.org/ NewsandMedia/PressCenter/79827.htm. For more detail on the state of the housing market and its importance to the nation's economy, see infra Part III.F.2.

14. See Steverman, supra note 1 . In 2008 , over $70 \%$ of homeowners with mortgages claimed the deduction. Sahadi, supra note 1.

15. See Robert M. Hardaway, The Great American Housing Bubble: The ROAD TO COLLAPSE 131-37 (2011) (discussing the inflationary role the mortgage interest deduction plays in the housing market and identifying it as "the tax provision which contributed most to the American Housing Bubble (and thus also to its ultimate collapse)”). Because of the societal difficulty identifying and seriously addressing speculative bubbles while they are occurring, the only effective strategy is for policymakers to target the conditions that create such bubbles in the first place. ROBERT J. Shiller, The SubPrime SOlution: How TODAY's Global FinanCial CRISIS HapPened, AND What To Do ABOUT IT 3-4 (2008).

16. See infra Part IV.A.3, B.3, C.3. 
market. Part II of this Comment examines how the mortgage interest deduction works, its history, and its intended benefits. Part III scrutinizes the deduction's inability to achieve its primary objective-increasing homeownership - and examines its negative effects on housing prices, household indebtedness, the environment, and wealth disparity. Accordingly, this Part argues that Congress should reform the deduction, discusses three basic options available for doing so, and introduces the long-term and short-term considerations that Congress must account for when adopting a new policy. Part IV discusses each of Congress's general options - eliminating the deduction, replacing it with a credit, or substantially modifying the deduction-and analyzes each option in light of continued housing market weakness. Ultimately, the analysis in Part IV concludes that Congress should reform the mortgage interest tax deduction by completely phasing it out over a number of years, with a trigger for the phase-out based on a metric of housing market health. Part V summarizes how completely phasing out the deduction will accomplish the twin objectives of long-term housing market health and accommodating the market's current fragility.

\section{BACKGROUND ON THE MORTGAGE INTEREST DEDUCTION}

\section{A. How the Deduction Works}

The Internal Revenue Code (the Code) only permits deductions for one type of personal debt, "qualified residence interest." 17 The Code defines qualified residence interest as interest arising from "acquisition indebtedness" or "home equity indebtedness" on a qualified residence. ${ }^{18}$ Acquisition indebtedness is purchase, construction, or improvement debt that is secured by a qualified residence. ${ }^{19}$ Home equity indebtedness is any nonacquisition indebtedness secured by the residence that does not exceed the difference between the fair market value and the acquisition

17. I.R.C. § 163(h) (2006).

18. Id. § 163(h)(2)(D), (3)(A)

19. Id. $\S 163(\mathrm{~h})(3)(\mathrm{B})(\mathrm{i})$. Common examples would be a fixed- or variable-rate mortgage to purchase a home or a second mortgage a homeowner uses to remodel. Acquisition indebtedness can also include debt remaining after refinancing a loan, but only to the extent of the unpaid principal before the homeowner refinanced. William $\mathrm{T}$. Mathias, Curtailing the Economic Distortions of the Mortgage Interest Deduction, $30 \mathrm{U}$. MiCH. J.L. REFORM 43, 47 (1996) (citing I.R.C. § 163(h)(3)(B)). 


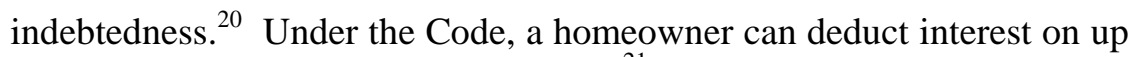
to $\$ 1$ million in acquisition indebtedness ${ }^{21}$ and the first $\$ 100,000$ in home equity indebtedness. ${ }^{22}$ Thus, a homeowner can potentially deduct interest on up to $\$ 1.1$ million of home-secured debt. ${ }^{23}$ However, the tax privilege for mortgage debt is not limited to a taxpayer's principal residence alone; a "qualified residence” includes both a taxpayer's principal residence and one other residence selected by the taxpayer. ${ }^{24}$

As a tax deduction, the mortgage interest deduction does not reduce tax liability dollar-for-dollar, as tax credits do. ${ }^{25}$ Instead, a deduction reduces taxable income by an amount directly proportional to a taxpayer's income tax rate. ${ }^{26}$ Consider the following example: On January 1, 2011, Alice and Ben each purchased a home with a $\$ 200,000$ mortgage at 5\% interest. The interest cost to each taxpayer was $\$ 10,000$ in the first year. Alice made \$100,000 in 2011 and paid at the 28\% tax rate, whereas Ben made $\$ 50,000$ and paid at the $15 \%$ tax rate. Under the mortgage interest deduction, Alice received a tax benefit of $28 \%$ of $\$ 10,000$, or $\$ 2,800$. Ben received a tax benefit of $15 \%$ of $\$ 10,000$, or $\$ 1,500$. In other words, of every dollar Alice spent on mortgage interest, the federal government gave twenty-eight cents back to her, while Ben received only fifteen cents back for every dollar he spent on mortgage interest in $2011 .^{27}$

20. I.R.C. $\S 163(h)(3)(C)(i)$. An example would be a loan of $\$ 50,000$ secured by a residence where the market value of the residence is \$500,000 and the amount of acquisition indebtedness is $\$ 450,000$. Unlike acquisition indebtedness, home equity indebtedness is not limited in what the proceeds may be used for. See id. § 163(h)(3)(C). It was this "interest-free" home equity cash homeowners used during the housing bubble to finance cars, boats, SUVs, wide-screen televisions, vacations, et cetera. See AARON ClAREY, BEHIND THE HOUSING CRASH: CONFESSIONS FROM AN INSIDER 27 (2008).

21. See I.R.C. § 163(h)(3)(B)(ii).

22. See id. § 163(h)(3)(C)(ii).

23. See id. § 163(h)(3)(B)(ii), (C)(ii). For perspective on this amount, the median home price at the peak of the housing market was $\$ 262,600$, while the average price was $\$ 329,400$. U.S. Census Bureau, Median and Average Sales Prices OF New Homes SOld in United States 11 (2011) [hereinafter U.S. Home SAlE PRICES], available at http://www.census.gov/const/uspricemon.pdf.

24. See I.R.C. § 163(h)(4)(A)(i). However, a household with two qualified residences may not deduct interest on debt exceeding an aggregated amount of \$1.1 million between the two residences. See id. § 163(h)(3)(B)(ii), (C)(ii).

25. See Freedom from Religion Found., Inc. v. Geithner, 715 F. Supp. 2d 1051, 1060-61 (E.D. Cal. 2010) (explaining the differences between tax credits and deductions). For a detailed example of the difference between tax credits and tax deductions, see infra pp. 1366-67.

26. See Freedom from Religion Found., 715 F. Supp. 2d at 1061 (explaining the influence of tax rates on the value of deductions).

27. See Chuck Marr \& Brian Highsmith, Ctr. On Budget and Policy Priorities, Reforming Tax Expenditures Can Reduce Deficits While MaKing the Tax Code More EFFicient and Equitable: ReCENT Proposals Underscore Bipartisan Support FOR REFORM 5 (2011), available at http://www.cbpp.org/files/4-15-11tax.pdf (discussing the same disparity demonstrated by different example). 
Accordingly, the higher one's income tax rate, the greater the proportional benefit from the deduction. ${ }^{28}$

To claim the mortgage interest deduction, taxpayers must itemize their taxes, which is only financially worthwhile if their total itemized deductions exceed the value of the standard deduction. ${ }^{29}$ Returning to the example of Alice and Ben, both taxpayers would itemize for tax year 2011 because the $\$ 10,000$ of mortgage interest they paid exceeds the standard deduction, which was $\$ 5,800$ for single taxpayers. ${ }^{30}$ Cynthia, a taxpayer who also purchased a home in 2011 with a \$100,000 mortgage, a 5\% interest rate, and thus $\$ 5,000$ in mortgage interest, would only itemize if she had other deductions totaling more than $\$ 5,800$. For Cynthia, the mortgage interest deduction provides no value unless combined with other deductions. ${ }^{31}$ This barrier - the need for itemized deductions to exceed the standard deduction - prevents nonitemizing homeowners from actually benefitting from the mortgage interest deduction. ${ }^{32}$

\section{B. History of the "Accidental Deduction"33}

In 2013, the mortgage interest deduction will celebrate its one hundredth anniversary as part of the federal tax code. ${ }^{34}$ Contrary to what its long history might suggest, the mortgage interest deduction is more a by-product of the nation's agrarian past than a longstanding policy preference for

28. See id.

29. Robert Lepore, Note, Bringing Balance to the Budget Debate: Challenging the Privileged Procedural Status of Regressive Tax Expenditures over Progressive Discretionary Spending Programs, 17 GEO. J. ON POVERTY L. \& POL’y 103, 107-08 (2010).

30. See Rev. Proc. 11-12, 2011-2 I.R.B. 297, 299, available at http://www.irs.gov/ pub/irs-irbs/irb11-02.pdf (stating 2011 standard deduction for individuals).

31. See Tax Reform Options: Incentives for Homeownership: Hearing Before the S. Comm. on Fin., 112th Cong. (2011) [hereinafter Hearing] (publication forthcoming), available at http://www.finance.senate.gov/hearings/hearing/?id=279c1381-5056-a0325260-1ce326dfc82b (statement of Dr. Richard K. Green, Director, Lusk Center for Real Estate, University of Southern California).

32. President's Advisory Panel on Fed. TAx Reform, Simple, Fair, ANd ProGrowth: Proposals To FIX America's TAX System 72 (2005). For a discussion of how this itemization barrier shifts benefits of the mortgage interest tax deduction away from lower income and middle class homeowners, see infra notes 75-76 and accompanying text.

33. For the article originating this moniker, see Dennis J. Ventry, Jr., The Accidental Deduction: A History and Critique of the Tax Subsidy for Mortgage Interest, 73 LAW \& CONTEMP. PROBS. 233 (2010).

34. See Tariff of 1913, Pub. L. No. 63-16, § 657, 38 Stat. 114, 167 (current version at I.R.C. § 163(h) (2006)). 
subsidizing homeownership. ${ }^{35}$ From 1913 until passage of the Tax Reform Act of 1986, all interest payments, whether related to personal or business expenses, were deductible. ${ }^{36}$ At the root of this across-the-board deductibility was a conflict between congressional tax policy and the practical limitations of the tax collection and reporting system in the early 1900s. ${ }^{37}$ Congress in 1913 sought to encourage business investment by allowing individuals to deduct interest from business-related debt. ${ }^{38}$ However, the inability to easily distinguish between personal and business assets in the early twentieth century made it less administratively burdensome to permit deductions for interest on all loans. ${ }^{39}$ Use of the deduction for mortgage interest would have been de minimis at that time because few taxpayers had any tax liability and those that did typically purchased their homes with cash. ${ }^{40}$

The Tax Reform Act of 1986 did away with the broad deduction for personal interest but maintained a specific deduction for mortgage interest. ${ }^{41}$ Although history might show the mortgage interest deduction to be a

35. See Mann, supra note 7, at 1351-52 \& 1352 n.17.

36. Id. at 1352. The Tax Reform Act of 1986 disallowed deductions for "personal interest," which is anything other than nonemployee business or trade interest, investment interest, passive activity interest, qualified residential interest, or interest related to tax payments. See Pub. L. No. 99-514, § 511, 100 Stat. 2085, 2246 (codified at I.R.C. $\S 163(\mathrm{~h})(1))$.

37. See Mann, supra note 7, at 1352 n.17.

38. See id.; see also Tariff of $1913 \S 657$ (“[I]n computing net income for the purpose of the normal tax there shall be allowed as deductions . . . all interest paid within the year by a taxable person on indebtedness ....”).

39. Mann, supra note 7, at 1352 n.17.

40. HARDAWAY, supra note 15, at 132. Further, the homeownership rate between 1910 and 1920 was under fifty percent. Historical Census of Housing TablesHomeownership, U.S. CENSUS BUREAU, http://www.census.gov/hhes/www/housing/census/ historic/owner.html (last revised Oct. 31, 2011).

41. See HARDAWAY, supra note 15, at 134 ("While this plan did indeed succeed in both simplifying the tax code while reducing tax rates, it left largely untouched the 800 pound gorilla tax deduction in the form of the home mortgage deduction ....”); Mann, supra note 7 , at 1352 . Whereas the Code treats mortgage interest differently from interest on other personal debt, courts in bankruptcy actions characterize mortgage debt as consumer debt and thus consider it subject to the same kind of abuse as other personal debts. See, e.g., In re Price, 353 F.3d 1135, 1138-39 (9th Cir. 2004) (affirming the lower court's dismissal of a Chapter 7 bankruptcy case on grounds that the individual primarily had consumer debt and that granting relief in light of the consumer debt would constitute substantial abuse of Chapter 7). It is especially peculiar Congress retained the mortgage interest deduction for second homes because the initial report from President Reagan's Treasury Department suggested that Congress act to curb tax incentives for large personal consumption expenditures, explicitly naming second homes as a target. See Robinson v. Comm'r, 119 T.C. 44, 53 (2002) (quoting DEP’T OF TREASURY, TAX REFORM FOR FAIRNESS, SIMPLICITY, AND ECONOMIC GROWTH: THE TREASURY DEPARTMENT REPORT TO THE PRESIDENT 83 (1984)). 
"tax policy accident," ${ }^{42}$ Congress justified retaining the deduction as a method of protecting the middle class and encouraging homeownership. ${ }^{43}$

\section{Intended Benefits: Achieving the American Dream}

Homeownership tends to improve people's lives both economically and socially, ${ }^{44}$ although some commentators dispute the extent of those benefits. ${ }^{45}$ Economically, home equity can provide a critical source of income stability when a taxpayer's income falls. ${ }^{46}$ Compared to renters, homeowners also have higher levels of accumulated wealth because

42. Mann, supra note 7, at 1352; see also HARDAWAY, supra note 15, at 131 (describing the origins of the mortgage interest deduction as "an historical accident now lost to the collective memory”); JosePH A. PECHMAN, TAX REFORM, THE Rich AND THE PoOR 86 (2d ed. 1989) ("Since the tax advantages of homeowners are regarded by politicians as untouchable, the act kept intact ... the deduction for interest on home mortgages ....”).

43. See, e.g., 132 Cong. REC. 14,916 (1986) (statement of Sen. Cohen); 132 Cong. REC. 14,524 (1986) (statement of Sen. Chafee) ("There is the feeling that the viability of the home mortgage interest deduction is so ensconced in our code and the American ethic, and I believe rightfully so. I think it is a major factor for people to own their own homes, which I believe is good for the country."); see also Fid. Int'l Currency Advisor A Fund, LLC v. United States, 747 F. Supp. 2d 49, 69 (D. Mass. 2010) (explaining that the mortgage interest deduction is one of many tax incentives encouraging homeownership instead of renting). At this point, it is important to note that although the mortgage interest deduction is the only type of personal debt deductible from income and is the largest single tax subsidy for housing, it is only one of many tax incentives for homeownership. See Tim Krumwiede \& Kathy Simons, Tax Benefits of Home Ownership, TAXES, July 2003, at 37. Closely related to the interest deduction because it provides a subsidy for just owning a home is the itemized deduction for state and local personal property taxes. I.R.C. § 164(a)(2) (2006). Other benefits include an exclusion for a portion of gain upon selling a principal residence, $i d$. $\S 121$, and a deduction for the use of a portion of the home or a separate structure on the property for business purposes, id. $\S 280 \mathrm{~A}(\mathrm{c})(1)$.

44. See Barbara A. Wiens-Tuers, There's No Place Like Home: The Relationship of Nonstandard Employment and Home Ownership Over the 1990s, 63 AM. J. Econ. \& Soc. 881, 883-85 (2004) (collecting studies showing homeowners' enhanced financial stability and participation in community organizations).

45. See Stephanie M. Stern, Reassessing the Citizen Virtues of Homeownership, 111 Colum. L. Rev. 890, 903-04 (2011) (explaining that the positive impact of homeownership on participation in civic organizations and local affairs is relatively modest when compared to similarly situated renters).

46. Wiens-Tuers, supra note 44 , at 883 . However, the converse of this is true as well; homeowners undergo a deep sense of financial instability when their largest financial asset is worth less than what they owe. See MARK Zandi, FinANCial SHock: A $360^{\circ}$ LOOK AT THE SubPrime Mortgage Implosion, AND How To Avoid the NeXt FINANCIAL CRISIS 217 (2009). 
homes provide a major share of their assets. ${ }^{47}$ Because homeowners can use equity in their homes - rather than direct support from government programs - to weather tough times, retire securely, or achieve other social welfare objectives, some characterize homeownership itself as a form of "private social insurance." ${ }^{48}$ Accordingly, government subsidies for private homeownership may replace some of the direct spending necessary to achieve similar social welfare outcomes. ${ }^{49}$

Beyond economic advantages, homeownership also provides a number of "spillover" social benefits, ${ }^{50}$ such as increased political activity, greater awareness of environmental issues, and better health outcomes. ${ }^{51}$ These secondary benefits also extend to the children of homeowners, who experience higher cognitive achievement in math and reading, ${ }^{52}$ as well as higher graduation rates. ${ }^{53}$ These cognitive and educational outcomes correlate with fewer behavioral problems and incidents of deviant behavior. $^{54}$ Just as government support for homeownership may replace

47. Wiens-Tuers, supra note 44 , at 883 . Primary residences represent more than half of homeowners' overall financial assets. Id. In 2006, American homeowners owned \$20 trillion in residential property, more than double the total amount of ownerheld property ten years earlier. ZANDI, supra note 46 , at 49.

48. Dalton Conley \& Brian Gifford, Home Ownership, Social Insurance, and the Welfare State, 21 Soc. F. 55, 62, 75 (2006). From this perspective, the mortgage interest deduction represents what Jacob S. Hacker terms the "[s]ubsidies and inducements" approach to social insurance. JaCOB S. HACKER, THE Divided Welfare State: The Battle over Public and Private Social Benefits in the United States 30 tbl.1.1 (2002). Hacker places approaches to social welfare on a spectrum ranging from direct provision to pure market allocation and identifies tax breaks as a chief means for government to encourage private behavior that enhances social welfare. See id.

49. See Conley \& Gifford, supra note 48, at 75. The logical end to this argument-if the mortgage interest deduction actually increases homeownership-is that ending the deduction might require increased direct social welfare spending in the future, mitigating at least a very minor portion of the fiscal impact of repealing the provision. See id. As discussed in Part III, however, the mortgage interest deduction actually fails to increase homeownership and contributes to the type of housing market instability and poor financial decisionmaking that put Americans at greater risk of financial ruin.

50. Wiens-Tuers, supra note 44 , at 883-85.

51. See Robert D. Dietz \& Donald R. Haurin, The Social and Private Micro-level Consequences of Homeownership, 54 J. URB. ECON. 401, 404, 434, 439 (2003) (collecting studies). Studies consistently suggest homeowners are more likely to vote than their renting counterparts. Id. at 430. On health, homeowners may take better care of the conditions of their homes, abating harmful building materials and preventing the growth of unhealthy conditions. See id. at 433.

52. Donald R. Haurin et al., The Impact of Homeownership on Child Outcomes 15 (Havard Univ. Joint Ctr. for Hous. Studies Low-Income Homeownership Working Paper Series, Paper No. LIHO-01.14, 2001), available at http://www.jchs.harvard.edu/sites/ jchs.harvard.edu/files/liho01-14.pdf.

53. Dietz \& Haurin, supra note 51, at 432. Families that own homes are less likely to move, reducing educational instability and boosting children's chances of completing a secondary education. Id.

54. Haurin et al., supra note 52, at 15. 
a portion of direct social spending, ${ }^{55}$ targeted homeownership incentives may be a worthwhile alternative to direct spending on education. ${ }^{56}$

Beyond its tangible advantages, owning real property is also intimately connected to foundational social and political values held since the founding of the Republic, namely, economic autonomy and political freedom. ${ }^{57}$ Homeownership remains a central component of the modern American conception of autonomy and social mobility, otherwise known as the "American Dream." 58 Indeed, owning a home is both a stand-alone aspect of the American Dream and fully integrated with that ideal's other facetseducational opportunity, social mobility, financial security, and a secure retirement ${ }^{59}$-because the spillover benefits of homeownership provide meaningful support to families seeking those other social goods. ${ }^{60}$

In spite of its popularity and the natural political protection afforded to the deduction by its association with the American Dream, the mortgage interest deduction and homeownership have serious social and economic implications that Congress cannot ignore. ${ }^{61}$

55. See supra notes $48-49$ and accompanying text.

56. Haurin et al., supra note 52, at 16. Donald Haurin, Toby Parcel, and Jean Haurin suggest that policymakers seeking to improve educational attainment should consider targeted homeownership programs as an alternative to direct government spending on education. Id. Again, the mortgage interest deduction does not provide the type of targeted homeownership benefit capable of increasing homeownership for renters on the cusp of being able to buy a home. See infra Part III.B. A shared equity program would provide a more targeted, less expensive alternative for renters on the cusp of affording a home. See infra note 173 and accompanying text.

57. See Geoffrey D. Korff, Reviving the Forgotten American Dream, 113 PEnN. ST. L. REV. 417, 422 (2008) ("Many of the framers ... despite the federalist and antifederalist differences among them, expounded on the interdependent, and often reinforcing, relationships among property ownership, economic autonomy, and political freedom.”). Korff argues, however, that the actual connection between property ownership, economic autonomy, and political freedom valued by the founding generation is significantly weaker or nonexistent today because property largely serves residential rather than economically productive purposes, as it did during the eighteenth century. Id. at 425-27.

58. E.g., Kristen David Adams, Can Promise Enforcement Save Affordable Housing in the United States?, 41 SAN DIEGO L. REV. 643, 659 (2004); Korff, supra note 57, at 428.

59. See Korff, supra note 57, at 428.

60. See Dietz \& Haurin, supra note 51, at 432-33, 439; Wiens-Tuers, supra note 44 , at $883-85$.

61. See infra Part III.C. 


\section{Mortgage INTEREST DEDUCTION DOWNSIDES AND REPLACEMENT POLICIES}

Although homeownership may provide some societal benefits, the home mortgage interest deduction is an ineffective and ultimately harmful approach to increasing homeownership. ${ }^{62}$ The deduction fails to increase homeownership rates, is the second most expensive "tax expenditure" in the Code, and incentivizes flawed housing and investment choices that drive up home prices and encourage suburban sprawl. ${ }^{63}$ For those reasons, fiscal and tax reform commissions appointed by both President George W. Bush and President Barack Obama have found that the mortgage interest deduction is a provision in need of reform. ${ }^{64}$

\section{A. Costs}

For fiscal years 2010 through 2014, the Joint Committee on Taxation (JCT) estimates the home mortgage interest tax deduction will result in $\$ 484.1$ billion of reduced revenue to the U.S. Treasury, making it the second costliest deduction in the tax code. ${ }^{65}$ That amount represents approximately $8.6 \%$ of federal tax expenditures for that period. ${ }^{66}$ For fiscal year 2011, the cost of the mortgage interest deduction represented approximately $7.2 \%$ of the of the year's budget deficit of $\$ 1.3$ trillion. ${ }^{67}$ Alone, those percentages may seem small, but when characterized as a subsidy for homeownership, the mortgage interest deduction represents more than twice the amount of direct spending on federal housing programs. ${ }^{68}$ Facing grave short- and long-term fiscal questions, ${ }^{69}$ and in

62. See infra Part III.B-C.

63. See infra Part III.C.

64. Nat'L Comm'N ON Fiscal Responsibility and Reform, The Moment of TRUTH 28-31 (2010) (President Obama), available at http://www.fiscalcommission.gov/ sites/fiscalcommission.gov/files/documents/TheMomentofTruth12_1_2010.pdf; PrESIDENT's AdVISORY PANEL ON FED. TAX REFORM, supra note 32, at 72 (President Bush).

65. H.R. REP. No. 112-58, at 50 tbl.10 (2011). The single largest subsidy in the Code is the exclusion of employer-paid health insurance premiums, long-term care insurance premiums, and health care contributions, which the JCT estimates will cost $\$ 659.4$ billion from 2010 to 2014. Id. at 54 tbl.10.

66. See id.

67. See id. at 50 tbl.10; Cong. Budget Office, Pub. No. 4474, The Budget And ECONOMIC OUTLOOK: FISCAL YEARS 2012 TO 2022, at 2 tbl.1-1 (2012), available at http://www.cbo.gov/sites/default/files/cbofiles/attachments/01-31-2012_Outlook.pdf.

68. See Christopher Howard, The HidDEn Welfare StATE: TAX ExPENDitures AND Social Policy IN THE UnITED States 28 (1997). When added to other tax benefits for housing, total tax-side housing subsidies eclipse the program budget of the entire U.S. Department of Housing and Urban Development. President's AdVISORY PANEL ON FED. TAX REFORM, supra note 32, at 72.

69. CONG. Budget OfFICE, ECONOMIC EFFECTS OF REDUCING THE FISCAL RESTRAint THAT Is SCHEDULED To OCCUR IN 20131 (2012), available at http://www.cbo.gov/sites/ 
a time of bipartisan agreement on the need to undertake 1986-style tax simplification, such large tax expenditures merit attention as targets for reform. ${ }^{70}$

\section{B. An Ineffective Homeownership Policy}

The primary justification for the mortgage interest deduction is encouraging homeownership, but comparative evidence suggests that the deduction has little to no effect on the U.S. homeownership rate. ${ }^{71}$ In 2005, 69\% of Americans owned their homes. ${ }^{72}$ Other developed countries without mortgage interest deductions had comparable rates, including the United Kingdom, Canada, and Australia. ${ }^{73}$ Those comparably high ownership rates suggest that mortgage interest subsidies are not necessary to achieve broad homeownership. ${ }^{74}$

One reason the mortgage interest deduction has little impact on the homeownership rate is that lower income households, whether they own a home or not, are unlikely to itemize their taxes. ${ }^{75}$ Thus, for renters on the cusp of being able to afford to buy a home, the deduction fails to provide the marginal benefit necessary to move them from renting to owning. ${ }^{76}$ Beyond the itemization barrier, those on the margin of buying

default/files/cbofiles/attachments/FiscalRestraint_0.pdf. For example, at the end of 2012, Congress faced a "fiscal cliff," a confluence of scheduled tax increases and automatic spending cuts. Id. Although inaction would have reduced the deficit, the suddenness of the tax increases and spending cuts would have harmed the economy, id., and many businesses were nervous Congress would not act. Nelson D. Schwartz, Partisan Impasse Drives Industry To Cut Spending, N.Y. Times, Aug. 6, 2012, at A1. 28-31.

70. See NAT'L COMM’N ON FISCAL RESPONSIBILITY AND REFORM, supra note 64, at

71. See President's Advisory PANEL On FED. TAX REFORM, supra note 32, at 72.

72. Id.

73. Id. In 2005, Canada's homeownership rate was 66\%, Australia's was 70\%, and the United Kingdom's was 69\%. Id. Canada provides an instructive foil on how privileges for housing investment fail to raise homeownership: although the United States has more capital invested in residential property than Canada, the two countries have comparable homeownership rates. See James M. Poterba, Taxation and Housing Markets, in CANADA-U.S. TAX COMPARISONS 275, 276 (John B. Shoven \& John Whalley eds., 1992).

74. PResident's AdVisory PANEL on Fed. TAX Reform, supra note 32, at 72.

75. Glaeser \& Shapiro, supra note 6, at 81.

76. See id. at 76-77. If those renters did purchase homes, they would likely be part of the $28 \%$ of homeowners who do not benefit from the mortgage interest deduction due to the itemization barrier. See Sahadi, supra note 1 . In contrast, the "full benefits" of the deduction are more readily counted on by households likely to itemize their deductions - those with higher incomes. ZANDI, supra note 46, at 51. 
homes are further disadvantaged because the deduction increases the cost of housing, pricing some buyers out of the housing market. ${ }^{77}$ Given its inability to actually increase homeownership, the mortgage interest deduction "is really not a pro-homeownership policy in any meaningful sense.,78

\section{A Regressive Provision with Harmful Side Effects}

Although the rate structure of the U.S. tax system is moderately progressive ${ }^{79}$ the mortgage interest deduction favors higher income earners in a way that reduces progressivity. ${ }^{80}$ For example, in $2008,72 \%$ of households with mortgages claimed the mortgage interest deduction. ${ }^{81}$ And although taxpayers earning over $\$ 200,000$ made up only $11 \%$ of the households claiming the deduction, those taxpayers' subsidies amounted to $32 \%$ of the total cost of the mortgage interest deduction. ${ }^{82}$ The disproportionate cost of providing the deduction to higher income taxpayers results in part from the larger value of deductions to those taxpayers. ${ }^{83}$

The average deduction value demonstrates the discrepancy in the deduction's benefit to higher income and middle class earners. ${ }^{84}$ In 2004, for households with incomes of over \$200,000, the average deduction was greater than $\$ 5,000 .^{85}$ Meanwhile, the average home mortgage deduction for taxpayers in all income brackets, including in the former group, was $\$ 591 .{ }^{86}$ The discrepancy in the value of the deduction based on income is more dramatically demonstrated by the $\$ 33,246$ average deduction taken by households earning $\$ 1$ million or more in 2006.87

77. See infra notes $96-99$ and accompanying text.

78. Glaeser \& Shapiro, supra note 6, at 81.

79. Joseph M. Dodge, The Logic of Tax: Federal Income Tax Theory and POLICY 2 (1989).

80. President's Advisory PAnel on Fed. TAX Reform, supra note 32, at 72. See generally Lepore, supra note 29, at 107-08 (discussing regressive tax expenditures).

81. See Sahadi, supra note 1.

82. Id. Seventy-five percent of the forgone funds went to households earning over $\$ 100,000$. Id

83. As in the example of Alice and Ben, Alice received a tax break of twenty-eight cents on every dollar spent on mortgage interest, whereas Ben's tax break was only fifteen cents of every dollar spent on interest. See supra notes 26-28 and accompanying text.

84. See President’s Advisory Panel on Fed. Tax Reform, supra note 32, at 72 fig.5.6.

85. Id.

86. Id.

87. TOM A. COBURN, Subsidies OF THE RICH AND FAMOUS 24 (2011), available at http://www.coburn.senate.gov/public/index.cfm?a=Files.Serve\&File_id=544ae3e7-195b- 
Because of the itemization barrier and the fact that more income means higher benefits, the mortgage interest deduction is an "upside-down subsidy" - taxpayers with historically high homeownership rates are the ones that receive the largest subsidies. ${ }^{88}$ As Professor Roberta Mann points out, Congress would never adopt a direct-payment housing subsidy providing \$5,000 to those making over \$200,000 while most American homeowners receive less than $\$ 600 .^{89}$

These tremendous subsidies encourage many homeowners to purchase larger, more costly homes than they would otherwise. ${ }^{90}$ Consider this example of how the deduction encourages the purchase of more expensive homes: Damon, who makes $\$ 100,000$ per year, has $\$ 30,000$ for a down payment, and pays a $28 \%$ tax rate, considers buying one of two homes. House $A$ is valued at $\$ 300,000$, and House $B$ is valued at $\$ 350,000$. With a fixed interest rate of $4 \%$, if Damon buys House $A$, he will receive a benefit of $\$ 54,300$ from the mortgage interest deduction over the life of the loan. ${ }^{91}$ However, if Damon buys House $B$, his benefit over the life of the loan would be approximately $\$ 64,400 .^{92}$ After accounting for the

40ad-aa84-334fdd6a5e1f. As striking as that subsidy level may seem, the most symbolic excess of the deduction is that it does not just subsidize brick and mortar homes, but yachts used as residences as well. See Press Release, Senator John D. Rockefeller, Rockefeller Offers Proposals To Trim \$1.29 Trillion from Deficit (June 30, 2011), available at LEXIS, 2011 TNT 129-34 (proposing to do away with the subsidy for yachts).

88. Mann, supra note 7, at 1361. Households with income at or above the median family income have a homeownership rate of $81.5 \%$, whereas those below the median income have a homeownership rate of $51.4 \%$. Press Release, U.S. Census Bureau, Residential Vacancies and Homeownership in the First Quarter 2011, at 9 tbl.8 (Apr. 27, 2011), http://www.census.gov/housing/hvs/files/qtr111/q111press.pdf.

89. See Mann, supra note 7, at 1362. For the numbers provided, see PrESIDENT's ADVISORY PANEL ON FED. TAX REFORM, supra note 32, at 72 fig.5.6.

90. Mark Andrew Snider, The Suburban Advantage: Are the Tax Benefits of Homeownership Defensible?, 32 N. KY. L. REV. 157, 170-71 (2005).

91. Mortgage Payment Calculator Results for a \$270,000, Thirty-Year, Fixed-Rate Loan at 4\% Interest, BANKRATE.COM, http://www.bankrate.com/calculators/mortgages/ mortgage-calculator.aspx (input "270,000” as "Mortgage Amount”; then input "30" as "Mortgage Term"; then input "4" as "Interest Rate"; then click "Show/Recalculate Amortization Table”). The total interest for a \$270,000 loan on House A is \$194,047.67. Id. If Damon's tax rate stays at a constant $28 \%$ for the life of the loan, the value of the mortgage interest deduction over that time is $\$ 54,333.35$. See id. (\$194,047.67 total interest $\mathrm{x} 0.28$ tax value of deduction $=\$ 54,333.35$ ).

92. Mortgage Payment Calculator Results for a $\$ 320,000$, Thirty-Year, Fixed-Rate Loan at 4\% Interest, BANKRATE.COM, http://www.bankrate.com/calculators/mortgages /mortgage-calculator.aspx (input "320,000" as "Mortgage Amount”; then input "30" as "Mortgage Term"; then input "4" as "Interest Rate"; then click "Show/Recalculate Amortization Table”). The total interest for a \$320,000 loan on House B is \$229,982.42. 
differences in principal and accrued interest, the mortgage interest deduction reduces the cost differential between Houses $A$ and $B$ by approximately $\$ 10,000$ over the life of the loan. ${ }^{93}$ In other words, Damon can buy the more expensive of the two homes, and the federal government will subsidize him for a portion of the additional cost. By encouraging prospective buyers like Damon to buy larger homes than they might otherwise, the mortgage interest deduction promotes suburban sprawl and the negative externalities associated with it-decreases in open space, increases in auto-related greenhouse gas emissions, and diminished vitality in urban cores. ${ }^{94}$ In short, the mortgage interest deduction allows those who would likely buy homes anyhow to purchase larger, more expensive homes. ${ }^{95}$

Subsidizing homeownership through the mortgage interest deduction also drives housing inflation, pricing many buyers out of the market. ${ }^{96}$ The inflationary impact of the deduction is most acute in regions where housing stock is limited, increasing prices by as much as $10 \%{ }^{97}$ Because the mortgage interest deduction contributes to higher housing prices, it actually reduces homeownership in inelastic housing markets. ${ }^{98}$ For middle and upper income households in such markets, the deduction decreases ownership by $3.7 \%$ and $3.4 \%$, respectively. ${ }^{99}$

Further, by subsidizing homeownership, the mortgage interest deduction encourages economically inefficient behavior by providing tax preferences for housing investment. ${ }^{100}$ Because of housing subsidies,

Id. Given a constant $28 \%$ tax rate, the value of the mortgage interest deduction over that time is $\$ 64,395.08$. See id. $(\$ 229,982.42$ total interest $\times 0.28$ tax value of deduction $=$ $\$ 64,395.08)$.

93. House $A$ : $\$ 270,000$ principal $+\$ 194,047.67$ interest $=\$ 464,047.67$ total loan cost. House B: $\$ 320,000$ principal $+\$ 229,982.42$ interest $=\$ 549,982.42$ total loan cost. Thus, before taking the mortgage interest deduction into account, the total cost differential between the two homes is $\$ \mathbf{8 5}, 934.75$. When the respective mortgage interest deductions are subtracted from the total costs, the total cost differential is reduced by $\$ 10,061.73$ to $\$ 75,873.02$.

94. See Mann, supra note 7, at 1375, 1380, 1384.

95. See Stern, supra note 45, at 931 n.193 (citing Glaeser \& Shapiro, supra note 6, at 40 ).

96. See HARDAWAY, supra note 15, at 133.

97. Dorothy A. Brown, Shades of the American Dream, 87 WASH. U. L. Rev. 329, 337 (2009).

98. See Hilber \& Turner, supra note 8, at 22.

99. Id.

100. See The President’s Econ. Recovery Advisory Bd., The Report on Tax ReFORM Options: SimplificATION, COMPLIANCE, AND CORPORATE TAXATION 46 (2010). A number of tax deductions, including the mortgage interest deduction, encourage taxpayers to make investment decisions that without tax subsidies they would not otherwise make. See id. Thus, subsidized investments displace more productive economic activities. See id.; see also SALANIÉ, supra note 2, at 49 ("[T]axation is unlikely to have 
the effective marginal tax rate on owner-occupied housing is zero. ${ }^{101}$ In contrast, business sector investment has an effective tax rate of $22 \% .{ }^{102}$ This disparity encourages investors to move capital toward residential assets rather than more productive capital goods. ${ }^{103}$ A JCT study modeling individual tax reform both with and without housing subsidies suggests that housing does indeed displace other investment ${ }^{104}$ and that long-run gross domestic product (GDP) would be higher without housing deductions. $^{105}$

\section{Is Homeownership Worth Subsidizing?}

Setting aside the negative consequences of the mortgage interest deduction, should the federal government subsidize homeownership at all? Although owning a home may provide wealth and financial stability in the long run, ${ }^{106}$ a home is also an "anchor" 107 that does not provide income and requires significant transaction costs for purchase and sale. ${ }^{108}$ These transaction costs, along with neighborhood ties, restrain homeowners

a large impact on total savings, although it clearly plays an important role in determining where the money is invested.”).

101. PRESIDENT's ADVISORY PANEL ON FED. TAX REFORM, supra note 32, at 71 fig.5.5.

102. Id.

103. Hearing, supra note 31 (statement of Dr. Richard K. Green); accord PREsident's AdVISORY PANEL ON FED. TAX REFORM, supra note 32, at 71 \& fig.5.5 ("[T]he economy-wide tax rate on housing investment is close to zero, compared with a tax rate of approximately 22 percent on business investment. . . . Too little [business] investment means lower worker productivity, and ultimately, lower real wages and living standards. While the housing industry does produce jobs and may have other positive effects on the overall economy, it is not clear that it should enjoy such disproportionately favorable treatment under the tax code.").

104. See Joint Comm. on Taxation, Macroeconomic Analysis of a Proposal TO BROADEN THE INDIVIDUAL INCOME TAX BASE AND LOWER INDIVIDUAL INCOME TAX RATES 11 tbl.4 (2006), available at https://www.jct.gov/publications.html?func=select\& id $=20$. JCT estimated that a tax code model without housing deductions would result in a $2.5 \%$ long-run increase in real producers' capital stock compared to current law. Id. In contrast, a model retaining housing deductions would decrease real producers' capital stock by $0.8 \%$. Id.

105. See id. at 10 tbl.2. The JCT-modeled tax reform that eliminated housing deductions would result in $0.9 \%$ greater growth in GDP compared to current law, while a model retaining the deductions would result in only $0.5 \%$ greater growth. Id.

106. See supra text accompanying notes 46-47.

107. Korff, supra note 57, at 440.

108. Mathias, supra note 19, at 55. 
from seeking work opportunities beyond their immediate geographic area. ${ }^{109}$

This anchoring also harms the broader economy. To stay in their homes, workers will remain in jobs for which they are poorly suited, hindering economic efficiency on the national level. ${ }^{110}$ For that and other reasons, some academics argue that too much homeownership can actually harm rather than help a nation's economy and that government homeownership subsidies are a misguided policy altogether. ${ }^{111}$ Even if Congress did decide to reduce homeownership subsidies, such a policy change would not necessitate a drop in homeownership, as the experience of other countries suggests. ${ }^{112}$

\section{E. Three Options for the Treatment of Mortgage Interest in Comprehensive Tax Reform}

For the reasons above, this Comment proceeds on the premise that Congress should use comprehensive tax reform to end the mortgage interest deduction as we know it. ${ }^{113}$ To do this, Congress has three general options: (1) eliminate the deduction, ${ }^{114}$ (2) replace the deduction with a tax credit, ${ }^{115}$ or (3) modify the workings of the deduction. ${ }^{116}$

109. Glaeser \& Shapiro, supra note 6, at 71-72.

110. See Mathias, supra note 19, at 55; The Road Not Taken, Economist (Mar. 19, 2009), http://www.economist.com/node/13331109.

111. See The Road Not Taken, supra note 110 ("A decade ago Andrew Oswald of the University of Warwick in Britain argued that excessive home-ownership kills jobs. He observed that, in Europe, nations with high rates of home-ownership, such as Spain, had much higher unemployment rates than those where more people rented, such as Switzerland. He found this effect was stronger than tax rates or employment law.”).

112. See supra text accompanying notes 71-74.

113. The Author assumes that Congress will likely retain some form of an income tax in a comprehensive tax reform package, although there are a number of other approaches, specifically consumption taxes, that academics argue are superior to the progressive income tax. For a discussion of various consumption tax proposals, see generally Alan Schenk, The Plethora of Consumption Tax Proposals: Putting the Value Added Tax, Flat Tax, Retail Sales Tax, and USA Tax into Perspective, 33 San Diego L. REV. 1281 (1996). However, even if Congress were to adopt some form of a consumption tax, the primary argument of this Comment would still apply and counsel strongly against any carve-out for mortgage interest other than necessary transition relief. See Daniel S. Goldberg, The Aches and Pains of Transition to a Consumption Tax: Can We Get There from Here?, 26 VA. TAX REV. 447, 482 (2007) (discussing the fact that all forms of a consumption tax would by definition tax home purchases unless Congress retained a special subsidy for them).

114. See infra Part IV.A.

115. See infra Part IV.B.

116. See infra Part IV.C. 
First, Congress could eliminate the deduction and treat all forms of interest on personal debt the same. ${ }^{117}$ This would complete the move toward neutral treatment of personal debt that started with the Tax Reform Act of $1986 .{ }^{118}$ Second, Congress could convert the mortgage interest deduction to a tax credit. ${ }^{19}$ Two presidential commissions and a number of think tanks have endorsed such an approach ${ }^{120}$ because credits are not subject to the itemization barrier ${ }^{121}$ and reduce tax liability dollar-for-dollar. ${ }^{122}$ Transforming the deduction into a credit would also provide a considerable source with which to offset tax rate cuts or reduce the deficit, though far less than elimination. ${ }^{123}$ Third, Congress could retain the deduction but make modifications like lowering the \$1.1 million cap, ending deductibility of home equity interest, ${ }^{124}$ or removing the subsidy for second homes and yachts. ${ }^{125}$ Some changes, like disallowing the deduction for yachts or second homes, would have a minor budgetary impact but address the more notorious excesses of the current deduction. ${ }^{126}$

117. Contra I.R.C. § 163(h)(2)(D) (2006) (exempting mortgage debt from characterization as nondeductible personal interest).

118. See HARDAWAY, supra note 15, at 132; Mann, supra note 7, at 1352. Eliminating the mortgage interest deduction would achieve what the Reagan Treasury Department originally set out to attain with I.R.C. § 163(h): an end to unnecessary tax subsidies for exceptional consumer expenditures. See Robinson v. Comm'r, 119 T.C. 44, 53 (2002) (quoting DEP'T OF TREASURY, supra note 41, at 83).

119. See Report Finds Agreement Among Organizations on Tax Reform, TAX Notes TODAY, May 26, 2011, available at LEXIS, 2011 TNT 102-37.

120. See id. (identifying the Bipartisan Policy Center, Economic Policy Institute, and Roosevelt Campus Network as supporters of converting the deduction into a credit).

121. ERIC TODER ET AL., URBAN InST., TAX POLICY CTR. \& What WORKS Collaborative, Reforming the Mortgage Interest Deduction 2 (2010), available at http://www.urban.org/uploadedpdf/412099-mortgage-deduction-reform.pdf.

122. JAMES J. FREELAND ET AL., FundAMENTALS OF FEDERAL INCOME TAXATION 971 (16th ed. 2011). As a simple example, assume Ellen earns $\$ 1,000$ per year, is taxed at a rate of $20 \%$, and can choose either a $\$ 100$ tax deduction or $\$ 100$ tax credit. The deduction would decrease Ellen's taxable income to \$900, which taxed at 20\% results in a $\$ 180$ final tax liability. With the credit, Ellen's taxable income is $\$ 1,000$, which, taxed at $20 \%$, results in computed tax liability of $\$ 200$. But the credit then reduces computed liability by a full $\$ 100$, for a $\$ 100$ final tax liability.

123. See infra text accompanying notes 252-54.

124. See, e.g., Coburn Budget Plan Would Scale Back Mortgage Interest Deduction, TAX NOTES TODAY, July 19, 2011, available at LEXIS, 2011 TNT 138-3.

125. See Rockefeller, supra note 87. A similar piece of legislation disallowing boats as qualified residences failed to pass in 1988. See WILLIAM D. POPKIN, FUNDAMENTALS OF FEDERAL INCOME TAX LAW 264 (1994); see also S. 624, 100th Cong. (1987).

126. See Coburn Budget Plan Would Scale Back Mortgage Interest Deduction, supra note 124; CONG. Budget OfFICE, Budget OptIONS 394 (2001), available at http://www.cbo.gov/sites/default/files/cbofiles/ftpdocs/27xx/doc2731/entire-report.pdf 
Proponents of each of these three approaches argue that the policy they advocate will ameliorate one or more of the negative aspects of the deduction under current law. ${ }^{127}$ Many commentators, however, fail to fully account for the short-term impact of adopting their preferred policy, such as how it will affect property values. ${ }^{128}$ But the short-term effects of a policy change should not be ignored; Congress might forgo an overhaul of the mortgage interest deduction if there is no apparent suitable way to reform the deduction without harming the housing market or homeowners. ${ }^{129}$

For that reason, Congress should simultaneously evaluate ideal longterm policies and explore options for minimizing the impact on property values. ${ }^{130}$ In previous tax reform efforts, Congress has adopted transition relief policies designed to ameliorate some of the hardship caused by the new laws. ${ }^{131}$ In order to understand which policies to adopt, however, the objectives and potential impact of changing the mortgage interest deduction must be clear.

\section{F. Implications of Changing the Mortgage Interest Deduction}

\section{Long-Term Considerations}

In deciding how to treat mortgage debt under the tax code, Congress should look to basic tax reform principles as its primary criteria. The objectives of a comprehensive tax overhaul include promoting economic

(indicating that disallowing mortgage interest deductions for second homes would have added $\$ 7.8$ billion in revenue from 2002 to 2011).

127. See, e.g., Ventry, supra note 33, at 283 (stating that replacing the mortgage interest deduction with a tax credit would "tie the subsidy to need rather than marginal tax rates, reduce complexity in taxpaying and tax administration by reducing itemizers," and "if permitted by budgetary realities, allow for rate reduction").

128. See, e.g., id. at 277-84. But see Mathias, supra note 19, at 70-72 (discussing the need for and options for transition relief in eliminating the mortgage interest deduction). That is not to say, however, that long-term considerations are not important. Indeed, two of the most salient reasons for eliminating the deduction, reducing housing inflation and preventing future housing bubbles, are important long-term considerations. See HARDAWAY, supra note 15, at 131; Hilber \& Turner, supra note 8, at 22.

129. See Donald Bruce \& Douglas Holtz-Eakin, Will a Consumption Tax Kill the Housing Market?, in Transition Costs of Fundamental TAX ReForm 96, 97 (Kevin A. Hassett \& R. Glenn Hubbard eds., 2001) ("The durability of the preferential tax treatment of owner-occupied housing reflects the widespread fear that reform (seemingly any reform) would harm the property values of homeowners.”).

130. See SHILleR, supra note 15, at 84 ("The idea that public policy should be aimed at validating the real estate myth, preventing a collapse in home prices from ever happening, is an error of the first magnitude. In the short run a sudden drop in home prices may indeed disrupt the economy, producing undesirable systemic effects. But, in the long run, the home-price drops are clearly a good thing.").

131. Kyle D. Logue, Tax Transitions, Opportunistic Retroactivity, and the Benefits of Government Precommitment, 94 MicH. L. REV. 1129, 1134 (1996). 
efficiency and growth, decreasing interference with private economic decisionmaking, easing the burdens of tax compliance, ${ }^{132}$ and treating similarly situated taxpayers equally. ${ }^{133}$

As a second criteria, Congress must also address those aspects of our tax system that contributed to the burst of the 2000s housing bubble and the Great Recession. ${ }^{134}$ Congress has already taken steps to address some mortgage excesses, ${ }^{135}$ and in 2011 the Obama Administration proposed winding down mortgage giants Fannie Mae and Freddie Mac. ${ }^{136}$ The federal government should not repeat the mistakes of the previous housing bubble by failing to change laws that stimulate unsafe overinvestment in housing. ${ }^{137}$ Accordingly, the mortgage interest deduction should be one aspect of broader housing policy reform. ${ }^{138}$

\section{Short-Term Considerations}

Whatever long-term tax policy Congress chooses, lawmakers must also account for the impact such a policy would have short term. A serious argument against changing the mortgage interest deduction is that doing

132. See GRAETZ, supra note 3, at 52.

133. See PEChMAN, supra note 42, at 44 ("[Deductions are] deviations from equal treatment [that] tend to be arbitrary.”).

134. Professor Robert M. Hardaway identifies the mortgage interest deduction as the primary culprit in the tax code responsible for the housing bubble. See HARDAWAY, supra note 15 , at 131 .

135. See Dwight M. Jaffee, Bank Regulation and Mortgage Market Reform, 8 BERKELEY BUS. L.J. 8, 16-17 (2011) (summarizing the mortgage-related provisions of the Dodd-Frank Wall Street Reform and Consumer Protection Act of 2010).

136. See U.S. Dep'T of Treasury \& U.S. Dep’t of Hous. \& Urban Dev., REFoRming AMERICA's HOUSING FinANCE MARKET: A REPORT TO CONGRESS 2 (2011), available at http://www.treasury.gov/initiatives/documents/reforming\%20america\%27s \%20housing\%20finance\%20market.pdf. Fannie Mae and Freddie Mac are governmentsponsored enterprises that ease housing finance by buying mortgages from other institutions or guaranteeing mortgage loans. Michael S. Barr, The Financial Crisis and the Path of Reform, 29 YALE J. ON REG. 91, 111 (2012). In 2008, when the housing market collapsed and losses from mortgage defaults mounted, the federal government had to bail out Fannie Mae and Freddie Mac. See Paul M. Jonna, Comment, In Search of Market Discipline: The Case for Indirect Hedge Fund Regulation, 45 SAN Diego L. ReV. 989, 1006 n.92 (2008).

137. See SHILLER, supra note 15, at 3-4 (discussing the American failure to identify and respond to speculative bubbles).

138. See HARDAWAY, supra note 15, at 172 (recommending policies to address conditions that led to the housing bubble). 
so will decrease property values during an already-weak housing market. ${ }^{139}$ Further, the centrality of housing to the overall economy makes changes in housing-related tax policy a major point of concern for policymakers. ${ }^{140}$ Accordingly, the state of the housing market should be an important but not overstated consideration in determining how to alter the mortgage interest deduction. ${ }^{141}$

Currently, the U.S. housing market is still recovering from the burst of the housing bubble in 2007, which caused a severe and sustained drop in home prices. ${ }^{142}$ The housing sector is, however, finally starting to turn around, ${ }^{143}$ and forecasters expect home prices to grow by approximately $3.8 \%$ from the third quarter of 2012 to the third quarter of $2013 .{ }^{144}$

Although the bottom of the housing market may be behind us, symptoms of housing market fragility remain. ${ }^{145}$ During the first quarter of 2012, 31.4\% of homes with mortgages were underwater. ${ }^{146}$ These homeowners owed more on their mortgages than their homes were worth, ${ }^{147}$ a circumstance that increases the chance of default. ${ }^{148}$ In short, foreclosures remain at elevated levels ${ }^{149}$ and the slow turnaround in the housing market continues to pose a challenge to the economic recovery. ${ }^{150}$

Housing market health is key to economic growth and stability because of its outsized and interconnected role in the U.S. economy. ${ }^{151}$ Housing market weakness heavily affects residential construction, state and local

139. See Hearing, supra note 31 (statement of Dr. Karl Case, Professor of Economics Emeritus, Wellesley College, and Senior Fellow, Joint Center for Housing Studies, Harvard University).

140. See ZANDI, supra note 46, at 215.

141. See Hearing, supra note 31 (statement of Dr. Karl Case).

142. See In re Smith, 435 B.R. 637, 643 (B.A.P. 9th Cir. 2010) (describing the housing market collapse); U.S. HOME SALE PRICES, supra note 23, at 11-12.

143. E.g., David Wessel, Housing Passes a Milestone, WALL ST. J., July 12, 2012, at A2; Nick Timiraos, Home Prices Climb as Supplies Dwindle, Wall St. J., August 8, 2012, at A1.

144. Fiserv, Inc., supra note 13.

145. E.g., Nick Timiraos, Mortgage Delinquencies Rose in Second Quarter, WALL ST. J. (Aug. 9, 2012, 11:08 AM), http://online.wsj.com/article/SB1000087239639044340 4004577579050532818834.html.

146. Les Christie, More than 30\% of Mortgage Borrowers Still Underwater, CNN Money (May 24, 2012, 5:23 AM), http://money.cnn.com/2012/05/24/real_estate/under water-mortgages/index.htm.

147. Id.

148. William G. Gale, Commentary, in Transition Costs of Fundamental Tax REFORM, supra note 129, at 115, 119.

149. See supra note 13.

150. FeD. Open MKT. COMM., June 19-20, 2012 Minutes 7 (2012), available at http://www.federalreserve.gov/monetarypolicy/files/fomcminutes20120620.pdf.

151. See Hearing, supra note 31 (statement of Dr. Karl Case). 
government funding, and consumer spending. ${ }^{152}$ For example, during the housing boom, the residential construction industry boosted real GDP by approximately $0.5 \% .{ }^{153}$ Accordingly, when the housing market faltered, the homebuilding decline led to decreased demand for building materials and less construction on related projects, such as infrastructure and schools. ${ }^{154}$

\section{OPTIONS FOR REFORMING THE DEDUCTION IN A FRAGILE HOUSING MARKET}

In light of the weaknesses of the mortgage interest deduction discussed in Part III, Congress should adopt a new tax policy toward mortgage debt. But because the housing market remains fragile, tax policy changes affecting the housing market must provide suitable transition relief to ensure that the housing market recovery is not unduly disrupted. As discussed below, completely eliminating the mortgage interest deduction best accomplishes the principles animating tax reform and more sustainable long-term housing market growth. Should Congress decide to continue subsidizing mortgage interest through the tax code, however, it should convert the deduction to a credit or substantially modify the deduction, in that order of preference. Congress can minimize any housing market disruption these policies might cause by concurrently adopting transition policies to protect property values and homeowners. ${ }^{155}$

\section{A. Option 1: Eliminate the Deduction}

\section{Long-Term Advantages and Disadvantages}

As the discussion in Part III reveals, the mortgage interest deduction is a costly, regressive tax provision that fails to achieve its primary objective. ${ }^{156}$ Rather than increasing homeownership, the deduction stimulates overinvestment in real estate and inflates home prices, which

152. ZANDI, supra note 46, at 216-17. Because many consumers make expenditures in part using the equity in their homes, falling home prices constrain overall consumer spending. See, e.g., Cong. Budget Office, Pub. No. 2834, Housing Wealth AND CONSUMER SPENDING 6 tbl.1, 12 tbl.2 (2007), available at http://www.cbo.gov/sites/ default/files/cbofiles/ftpdocs/77xx/doc7719/01-05-housing.pdf.

153. ZANDI, supra note 46, at 216.

154. Id.

155. See infra Parts IV.A.3, B.3, C.3.

156. See supra Part III. 
undermine economic growth and affordability for future generations. ${ }^{157}$ For those reasons, many commentators support complete elimination of the mortgage interest deduction. ${ }^{158}$

Unlike a modification of the deduction or conversion to a tax credit, complete elimination broadens the tax base most significantly. ${ }^{159}$ This broader tax base conforms with comprehensive tax reform priorities, ${ }^{160}$ as well as the principles of neutrality and efficiency. ${ }^{161}$ By eliminating the deduction and moving the tax system closer to neutrality, this approach would represent an important step in ending federal government policies that contributed to the housing bubble. ${ }^{162}$ When mortgage interest is nondeductible, taxpayers prioritize paying down their mortgages more quickly. ${ }^{163}$ One example of that effect is in Australia, which has no deduction for mortgage interest. ${ }^{164}$ Although the amount of mortgage debt Australian homeowners take on is similar to their American counterparts, homeowners in that country paid down mortgage debt more quickly than in the United States. ${ }^{165}$

These types of household shifts in spending priorities to pay down mortgages have important benefits for homeowners and the economy. ${ }^{166}$ First, homeowners who pay off their mortgages more quickly feel more financially secure and are typically in better financial shape because they have less outstanding debt. ${ }^{167}$ Second, although a shift to paying down

157. See supra notes $96-105$ and accompanying text.

158. See, e.g., Mann, supra note 7, at 1393; Mathias, supra note 19, at 45.

159. Alex M. Brill \& Alan D. Viard, AEI Says Tax Base Broadening Should Target Biggest Distortions, TAX NOTES TODAY, Sept. 28, 2011, available at LEXIS, 2011 TNT 188-39.

160. Id.

161. Professor Joseph Dodge explains that " $[t]$ he ideal of neutrality is the notion that the tax system should not unduly favor one type of economic activity over another, i.e., economic actors should be able to perform on a 'level playing field." 'DODGE, supra note 79, at 287. A neutral tax policy is "presumably 'allocatively efficient.'” Id. at 288.

162. See SHILLER, supra note 15 , at 172.

163. Eric Toder et al., Tax Policy Center Compares Revenue-Raising Options for Deficit Reduction, TAX NOTES TODAY, Nov. 23, 2011, available at LEXIS, 2011 TNT 226-39.

164. Hearing, supra note 31 (statement of Dr. Richard K. Green).

165. See id. (citing Dennis R. Capozza et al., Taxes, Mortgage Borrowing, and Residential Land Prices, in ECONOMIC EFFECTS OF FundAMENTAL TAX REFORM 171 (Henry J. Aaron \& William G. Gale eds., 1999); DENNIS R. CAPOZZA ET AL., TAXES AND HOUSE PRICES (1998), available at http://www.umich.edu/ reecon/restate/faculty/ Capozza/tax1097b.pdf). Similarly, in Canada, "[t]he absence of a tax deduction for mortgage interest probably increases the incentive to pay down debt," and may explain, in part, why Canada's delinquent mortgage loan rate is approximately one-tenth that of the United States. Alex J. Pollock, Why Canada Avoided a Mortgage Meltdown, WALL ST. J., Mar. 19, 2010, at A17.

166. Hearing, supra note 31 (statement of Dr. Richard K. Green).

167. See id. This also coincides with economist Mark Zandi's advice for how to personally prepare for the next financial crisis-whenever it may come. See ZANDI, supra note 46, at 243 ("We will all have to save more and be more careful how we 
mortgages will slow debt-driven consumer spending in the overall economy, that type of spending can become too excessive. ${ }^{168}$ During rosy economic periods, many homeowners spend abundantly rather than pay down tax-privileged mortgage debt. ${ }^{169}$ For example, many homeowners during the last housing boom spent $10 \%$ more than they took in. ${ }^{170}$ But when the housing market crashed and the broader economy floundered, consumers had to cut personal spending, landing another blow to an economy accustomed to consumer excess. ${ }^{171}$ A neutral tax policy that does not favor mortgage debt will help assuage substantial booms and busts like those encouraged by the current policy. ${ }^{172}$

A significant advantage of eliminating the deduction rather than replacing it with a credit or modifying it is that elimination provides Congress with the greatest amount of revenue flexibility with which to lower tax rates, cut the deficit, or invest in more targeted, nontax homeownership programs. ${ }^{173}$ If the deduction had been eliminated in 2010, it would have resulted in between $\$ 879$ billion and $\$ 1.26$ trillion in increased revenue over ten years, producing significant revenue to direct toward the aforementioned purposes. ${ }^{174}$

invest. Instead of piling into the next new thing, we should be diversifying away from whatever is appreciating quickly.”).

168. See Hearing, supra note 31 (statement of Dr. Richard K. Green).

169. See ZANDI, supra note 46, at 217-18; see also CONG. BUDGET OfFICE, supra note 152, at 6 tbl.1 (showing consumers' general propensity to increase spending using housing wealth).

170. ZANDI, supra note 46 , at 218.

171. See id. at 218-19. The Congressional Budget Office estimates that a price decline of $10 \%$ could, by itself, decrease GDP by between $0.4 \%$ and $1.4 \%$. CONG. BUDGET OFFICE, supra note 152, at 12 tbl.2.

172. See Hearing, supra note 31 (statement of Dr. Richard K. Green).

173. If Congress did wish to maintain a small, targeted incentive for homeownership that only provides a subsidy for those on the cusp of buying a home, one such proposal is to invest in state-based trust funds that would provide downpayment assistance to eligible homeowners and share home equity proceeds with the homeowner. See Rick Jacobus \& David M. Abromowitz, A Path to Homeownership: Building a More Sustainable Strategy for Expanding Homeownership, 19 J. AfFordABle Housing \& COMMUNITY DEV. L. 313, 316-18 (2010). Jacobus and Abramowitz argue that an advantage of this approach is that it weeds out homeowners who do not need homeownership assistance because participants would be required to share the equity in their home with the trust fund in order to replenish the fund. See id. at 318.

174. TODER ET AL., supra note 121 , at 18 tbl.1. The variability in the revenue projections is due to two things: (1) whether researchers account for behavioral modifications resulting from the deduction's elimination, such as selling taxable assets in order to pay down mortgage debt, and (2) whether current tax policies such as the Bush tax cuts and patch for the alternative minimum tax are extended. See id. at 8, 18 tbl.1. 
Without a decrease in marginal tax rates - though that is not the object of this Comment - a strict elimination of the mortgage interest deduction would result in higher tax liability. ${ }^{175}$ However, because the mortgage interest deduction disproportionately favors higher income groups, the percentage change in after-tax income would affect higher income groups more greatly than lower and middle income groups. ${ }^{176}$ If the deduction were simply eliminated, the average household in the middle-income quintile earning \$43,678 in after-tax income would have an increased liability of $\$ 215$, or approximately $0.5 \% .{ }^{177}$ Those in the fourth-highest quintile earning $\$ 71,839$ would pay $\$ 689$ more, a change in liability of approximately $1 \% .{ }^{178}$ Meanwhile, for households in the ninety-fifth to ninety-ninth percentile earning $\$ 259,935$, the increase would be $\$ 4,234$, or approximately $1.6 \%$ of after-tax income. ${ }^{179}$

The greatest advantage eliminating the mortgage interest deduction offers is less housing market volatility and greater affordability in the long run. For example, eliminating the mortgage interest deduction and property tax deduction would actually increase the homeownership rate of young Americans in urban areas because those deductions actually raise home prices by an amount greater than the decrease in tax liability they provide. ${ }^{180}$ In high-cost regions, where the deduction has the greatest inflationary effect, eliminating the deduction will cause the greatest drop in home prices. ${ }^{181}$ In the long run, however, those price decreases will make owning a home easier in places like California. ${ }^{182}$

Accordingly, eliminating the mortgage interest deduction will result in greater market-based allocation of resources and lower, stabilized home prices in the long run. ${ }^{183}$ Further, by eliminating the deduction, Congress

\footnotetext{
The $\$ 879$ billion figure represents a model with behavior changes and extension of current policies. Id. at 18 tbl.1. The $\$ 1.26$ trillion figure represents a model of static behavior and no extension of current policies. Id.

175. See id. at 19 tbl.2a.

176. See id.

177. Id.

178. Id.

179. TODER ET AL., supra note 121, at 19 tbl.2a. The largest increase in tax liability would occur in households in the eightieth to ninety-ninth percentiles. Id. at 16. "The very highest income taxpayers, however, would experience a relatively small loss in income because their mortgage costs as a share of income are lower than for other groups.” Id.; see id. at 19 tbl.2a.

180. Steven C. Bourassa \& Ming Yin, Tax Deductions, Tax Credits and the Homeownership Rate of Young Urban Adults in the United States, 45 URB. STUD. 1141, 1158 (2008), available at http://usj.sagepub.com/content/45/5-6/1141.full.pdf.

181. See Richard K. Green ET AL., TAXes, Mortgage Borrowing and House Prices

22 (1996), available at http://ww.bus.wisc.edu/realestate/documents/culer606.pdf.

182. See Bourassa \& Yin, supra note 180, at 1158.

183. See Mathias, supra note 19, at 67.
} 
would have a significant source of revenue with which to lower tax rates or decrease the structural budget deficit. ${ }^{184}$

\section{Short-Term Consequences}

In the short-run, an immediate elimination of the mortgage interest deduction would lower home prices and extend economic pain caused by the burst of the housing bubble, financial crisis, and Great Recession. ${ }^{185}$ Not surprisingly, considering evidence that the mortgage interest deduction contributes to housing inflation, ${ }^{186}$ studies on eliminating the mortgage interest deduction suggest home prices would drop between $2 \%$ and 13\% nationally, with significant variations by region. ${ }^{187}$ Thus, immediately eliminating housing subsidies would generally lower home prices and increase negative equity, ${ }^{188}$ which would undermine consumer confidence and spending. ${ }^{189}$

On a national scale, these "transition losses" 190 accompanying a sudden elimination of the mortgage interest deduction-depending on the timing of its effective date-could slow appreciation or cause depreciation in the housing market. ${ }^{191}$ Even if Congress were to eliminate the deduction in a comprehensive tax reform package that lowered tax rates and offset the cost of mortgage interest with lower tax liability, taxpayers would still begin to divest in housing and shift investments toward more economically productive assets. ${ }^{192}$

Further, looking beyond the macroeconomic effects of eliminating the deduction, many homeowners purchased homes with the expectation

184. See id.

185. See Hearing, supra note 31 (statement of Dr. Richard K. Green).

186. Hilber \& Turner, supra note 8, at 6; Steverman, supra note 1.

187. See GREEN ET AL., supra note 181, at 23; Steverman, supra note 1.

188. See Gale, supra note 148 , at 119.

189. See ZANDI, supra note 46 , at 217.

190. See Logue, supra note 131, at 1133.

191. See Hearing, supra note 31 (statement of Dr. Richard K. Green); see also Michael P. Devereux, Introduction to THE Economics of TAX Policy 1, 5-6 (Michael P. Devereux ed., 1996) (discussing the United Kingdom's phase-out of mortgage interest tax benefits and the resulting "slump" in property values).

192. See Mathias, supra note 19, at 67. The redistribution of investment to marketbased equilibrium would most obviously harm the real estate development industry, which opposes making substantial changes to the status quo. See Hearing, supra note 31 (statement of Dr. Robert D. Dietz, Assistant Vice President, National Association of Home Builders). 
that they could deduct mortgage interest in the future. ${ }^{193}$ Changing the subsidy too quickly or dramatically would impose unfair hardship. ${ }^{194}$ If, for example, Congress immediately eliminated the deduction without any related drop in marginal tax rates, ${ }^{195}$ a household expecting the deduction would be subject to a dual financial blow: a drop in home equity and higher tax liability. ${ }^{196}$ Without lowering marginal rates, that change would result in \$215 in increased tax liability for households earning about $\$ 44,000$ in after-tax income. ${ }^{197}$ For households earning approximately $\$ 72,000$ in after-tax income, the change could increase tax liability by an average of $\$ 689 .{ }^{198}$

Depending on how Congress structured rate cuts in tax reform, taxpayers may be satisfied with overall lower tax rates and liability but no mortgage interest deduction. ${ }^{199}$ For example, the plan put forward by the Bipartisan Policy Center would change the current tax system, consolidating the current rate structure-six rates ranging from $10 \%$ to $39.6 \%$ - to two rates- $15 \%$ and $27 \% .{ }^{200}$ Those going from a higher rate to a lower one may forgive not being able to deduct mortgage interest if the reform delivers overall lower tax liability. ${ }^{201}$ Thus, fairness and reliance concerns about ending the deduction could, for many taxpayers, be addressed by decreases in the marginal tax rate. However, homeowners would still be subject to a modest decrease in home prices and related

193. See Hearing, supra note 31 (statement of Dr. Richard K. Green).

194. See id. But see Louis Kaplow, An Economic Analysis of Legal Transitions, 99 HARV. L. REV. 509, 523-24, 577, 616 (1986) (arguing that taxpayers should not have a normative expectation that tax policy will never change and that investors should treat the risk of government policy changes like the risk associated with traditional market forces-by incorporating it into their overall analysis in deciding whether to make an investment).

195. This raises a question that cannot be addressed in this Comment: what should Congress do with the revenue raised by ending the tax preference for mortgage debt? Depending on how marginal income tax rates are lowered in a comprehensive tax reform package, these would-be tax increases on those who claimed the mortgage interest deduction could actually result in lower tax liability or liability somewhere between current law and these figures. See ToDER ET AL., supra note 121, at 19 tbl.2a.

196. See id. (showing that eliminating the mortgage interest deduction would result in an increase in tax liability for $23.5 \%$ of U.S. households).

197. Id. This represents households in the fortieth to sixtieth percentiles for aftertax income. Id.

198. Id. This represents households in the sixtieth to eightieth income percentiles. Id.

199. See Steverman, supra note 1.

200. Pete Domenici \& Alice Rivlin, Bipartisan Policy Ctr., Restoring America’s Future: REVIVING THE ECONOMY, CutTING SPENDING AND DEBT, AND CREATING A SiMPLE, PRO-GROWTH TAX SySTEM 33 (2010). Although the plan would convert the mortgage interest deduction to a tax credit, it is used here only to demonstrate rate decreases and simplification. See id. at 33-34.

201. See Steverman, supra note 1. 
consequences for home equity because the government would no longer encourage overinvestment in housing. ${ }^{202}$

\section{Appropriate Transition Relief}

In eliminating the home mortgage interest deduction, Congress would be wise to adopt transition relief capable of gradually eliminating the deduction without shocking the housing market. ${ }^{203}$ Using transition policies for tax changes is common, ${ }^{204}$ and basic methods include phasingin, delaying, or grandfathering a law's effective date. ${ }^{205}$ To determine what, if any, transition relief to provide, policymakers must evaluate the type of transition losses or windfall gains the new law will likely cause. ${ }^{206}$ For example, in the Tax Reform Act of 1986, Congress disallowed deductions for investment interest in excess of net investment income but gradually phased in the disallowance by set percentages for tax years 1987 through $1990 .^{207}$ A properly structured transition policy can minimize concerns about eliminating the mortgage interest deduction by preventing a sudden increase in tax liability for individual taxpayers, minimizing disruption of the housing market, and reducing the likelihood that businesses and individuals affected by the change will resist it. ${ }^{208}$

One proposal is to phase out the mortgage interest deduction by reducing the cap on qualified residence debt from $\$ 1$ million by increments of $\$ 100,000$ over a ten-year period. ${ }^{209}$

202. See supra note 187 and accompanying text.

203. See Hearing, supra note 31 (statement of Dr. Richard K. Green).

204. In enacting the Tax Reform Act of 1986, Congress used a number of transition policies to ease tax system changes where necessary. See, e.g., Bethlehem Steel Corp. v. United States, 270 F.3d 135, 136 (3d Cir. 2001) (discussing a provision of the Act allowing domestic steel companies, which were struggling at the time, to "cash out" unused investment credits before the credits were repealed); Hosp. Servs. Ass'n of Ne. Pa. v. United States, 78 Fed. Cl. 434, 435 (2007) (citing Tax Reform Act of 1986, Pub. L. No. 99-514, § 1012, 100 Stat. 2085, 2390) ("[The] Act contained provisions designed to transition [Blue Cross/Blue Shield] organizations into taxation ....”).

205. Logue, supra note 131, at 1134.

206. See id.

207. See I.R.C. § 163(d)(6) (2006). Congress limited the deduction of investment interest in excess of net investment income to $35 \%$ in $1987,60 \%$ in $1988,80 \%$ in 1989 , and $90 \%$ in 1990. See id. By 1991, such excesses were entirely disallowed as deductions. See id.

208. See Charles E. McLure, Jr., Where Tax Reform Went Astray, 31 Vill. L. Rev. 1619, 1640-41 (1986).

209. See Hearing, supra note 31 (statement of Dr. Richard K. Green); CoNG. BuDGET Office, Pub. No. 4212, Reducing the Deficit: Spending And Revenue Options 146 
For homeowners, a phase-out would provide time to plan for the decrease and gradually encourage homeowners to pay down their mortgages more quickly. ${ }^{210}$ For the housing market, a phase-out would provide an orderly, long-range drawdown and affect housing prices slowly, impacting only the highest-valued homes first. ${ }^{211}$ Relatedly, phasing out the deduction provides housing-related industries, such as real estate sales and residential construction, with adequate time to adjust their business activities. ${ }^{212}$

An additional benefit of a phase-out is that, like the temporary 20082010 homebuyer tax credit, it might provide current renters looking to purchase a home with a marginal incentive to do so sooner rather than later in order to take advantage of the deduction before it disappears. ${ }^{213}$ On the other hand, because eliminating the mortgage interest deduction will cause more dramatic decreases in home prices in high-cost regions, ${ }^{214}$ and those regions would be impacted by a phase-out first, other potential homeowners might wait to purchase homes until anticipated price decreases set in. ${ }^{215}$ Thus, a phase-out might cause some potential homeowners to purchase a home sooner, whereas others in high-cost areas might stay on the sidelines in anticipation of noticeably lower prices following a phase-out. ${ }^{216}$

(2011), available at http:/www.cbo.gov/sites/default/files/cbofiles/ftpdocs/120xx/doc12085/

03-10-reducingthedeficit.pdf; Mathias, supra note 19, at 71 n.179.

210. See supra notes 163-65 and accompanying text.

211. See Hearing, supra note 31 (statement of Dr. Richard K. Green).

212. See Mathias, supra note 19, at 71-72 (noting that those industries need "time to adjust protection because many real estate projects develop over many years").

213. See Jacobus \& Abromowitz, supra note 173, at 335 (noting that Congress intended the homebuyer tax credit to provide "an immediate economic stimulus to help prevent further decline in the U.S. housing market”).

214. See Pamela J. Jackson, Cong. Research Serv., Fundamental Tax Reform: Options fOR THE Mortgage InTEREst Deduction 18 (2008) (citing Capozza et al., supra note 165 , at 190 ).

215. See Jack Hough, Shopping for a House? Consider Waiting 9 Months, SMART MONEY (Jan. 29, 2010), http://www.smartmoney.com/invest/markets/shopping-for-ahouse-consider-waiting-6-months/?mg=com-sm (explaining that homebuyers could save money by waiting to buy a home after a temporary homebuyer tax credit expired because home prices would drop once government-stimulated demand subsided).

216. See Heather M. Field, Taxpayer Choice in Legal Transitions, 29 VA. TAx REV. 505, 508 n.12 (2010). Delaying the transition to a new tax policy, whether by phasing it in or delaying the effective date, allows taxpayers to accelerate a deductible activity or wait until the favorable new law applies. See id. Accordingly, delaying the effective date of a complete elimination of the mortgage interest deduction could lead to two scenarios. For example, if Congress decided to delay elimination until 2017, potential homeowners might accelerate home purchases in order to claim the deduction for their first few years of ownership. See id. Those potential homeowners should be wary, however, that the same tax change accelerating their home purchase might temporarily stimulate demand and increase home prices, minimizing or wiping out the value of the deduction. See Hough, supra note 215 (discussing similar behavior related to a homebuyer tax credit). That same phenomenon might cause other potential buyers to wait for the 
A phase-out does yield disadvantages, however, including little revenue early in the transition decade ${ }^{217}$ and a sudden end to the deduction for most homeowners at the end of the decade. First, as an example, if Congress initiated the phase-out in 2014, gradually eliminating the deduction would increase revenues by a total of only $\$ 14$ billion in the first three years. ${ }^{218}$ In contrast, the subsequent five years would see a total of $\$ 215$ billion in revenue. ${ }^{219}$ Accordingly, unless Congress structured tax reform to increase the deficit in the near-term and decrease the deficit as revenues from the phase-out increased, any tax rate reduction would have to be more modest at the outset as well. ${ }^{220}$

Second, as the transition decade reached an end, the phase-out would affect a broad swath of homeowners whose mortgage debt approximated the median home price of between $\$ 200,000$ and $\$ 300,000 .^{221}$ For example, based on 2009 home values, cutting the cap on the deduction by $\$ 100,000$ per year for the first five years will affect fewer than $10 \%$ of U.S. homeowners. ${ }^{222}$ Meanwhile, in the eighth year alone, the cap decrease from $\$ 300,000$ to $\$ 200,000$ would affect nearly $18 \%$ of homeowners. ${ }^{223}$ Congress might desire this phase-out structure to place the most immediate transition losses on those homeowners with the most expensive homes, delay the impact on those with modestly priced homes, and postpone the impact on a broad swath of the housing market. ${ }^{224}$

temporarily high demand and inflationary effect of the mortgage interest deduction to dissipate after 2017, hoping to buy a home for less. See id.

217. See Cong. BUdGet OfFICE, supra note 209, at 146.

218. Id.

219. Id.

220. See Mathias, supra note 19, at 72.

221. See U.S. Home SAle PrICES, supra note 23, at 12. Even at the height of the housing bubble in 2006, the median home price was only $\$ 257,000$. See id. at 11.

222. See U.S. Census BuREau, 2009 NATIONAl VAlue, PuRChase Price, and SourCe OF DOWNPAYMENT-OWNER-OCCUPIED UNITS tbl.3-14 (2009) [hereinafter 2009 NATIONAL HOME VALUE], available at http://www.census.gov/housing/ahs/files/ahs09/3-14.xls.

223. See id.

224. For example, even though New York's housing market is among the most expensive in the nation, the 2009 median home value in the metropolitan area was \$400,000. See U.S. Census Bureau, 2009 New York City Metropolitan Area

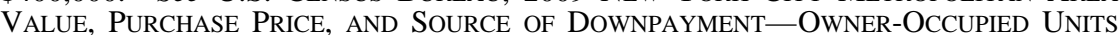
tbl.3-14 (2009), available at http://www.census.gov/housing/ahs/files/newyork09/tab314.xls. An open question is whether a future Congress would get cold feet and halt the phase-out when it came time for it to "hit" a large group of taxpayers. See, e.g., Peter Suderman, The Doc Fix: Another Reminder that Congress Can't Stick to Its Own Deficit Reduction Plans, ReAson.com Hit \& Run Blog (Jan. 2, 2013, 1:47 PM), http://reason. $\mathrm{com} / \mathrm{blog} / 2013 / 01 / 02 /$ the-doc-fix-another-reminder-that-congre (explaining that in 1997 
One alternative would be to decrease the cap according to the percentage of U.S. owner-occupied homes affected each year. Thus, in the first year, the cap would be reduced to approximately $\$ 500,000$, impacting about $10 \%$ of homeowners. ${ }^{225}$ From there, year-to-year decreases in the dollar value of the cap would slow as they approached the median home value in the fifth year. ${ }^{226}$ Because this approach would affect more homeowners with high-value deductions sooner in the transition decade, it would also provide greater revenue up front and more flexibility in offsetting tax rate decreases. ${ }^{227}$ This also has the advantage of not back loading the impact of the phase-out such that it hits a large number of taxpayers in a one to two year period.

As another alternative, Congress could structure the phase-out to equalize the revenue impact over a defined period. For example, if the deduction would result in $\$ 879$ billion in lost revenue over a ten-year period, ${ }^{228}$ Congress could structure the phase-out to raise $\$ 87.9$ billion per year over that same period. This would ease rate-reduction planning.

Whether Congress chooses to phase out the deduction by a nominal amount, by the percentage of homeowners impacted, or in a manner that equalizes revenues, beginning any phase-out during a weak housing market may undermine recoveries in the housing market and the broader economy. ${ }^{229}$ For that reason, some suggest Congress should adopt additional transition relief in the form of a trigger tied to the health of the housing market. ${ }^{230}$ For example, Richard K. Green proposes that phasing out the mortgage interest deduction "not begin until the Federal Housing Finance Agency's house price index shows year-over-year growth equal to the rate of consumer price index growth."231 Creating an automatic trigger

Congress passed a deficit-cutting measure affecting doctors' reimbursement rates under Medicare but has not permitted the cuts to go into effect since 2002).

225. See 2009 National Home Value, supra note 222, at tbl.3-14.

226. See id.

227. For a discussion of the basic revenue considerations of eliminating the deduction, see supra notes $173-74$ and accompanying text.

228. TODER ET AL., supra note 121, at 6, 18 tbl.1.

229. See Hearing, supra note 31 (statement of Dr. Richard K. Green); see also Michael J. Graetz, Legal Transitions: The Case of Retroactivity in Income Tax Revision, 126 U. PA. L. REV. 47, 87 (1977) ("If the impact on wealth of such a [tax law] change is large, efficiency and fairness concerns may suggest that phased-in or delayed effective dates be used to mitigate that impact.”).

230. See Hearing, supra note 31 (statement of Dr. Richard K. Green).

231. Id. Why not just adopt a trigger to completely eliminate the deduction? Like a delayed effective date, a trigger for immediate elimination of the deduction could motivate potential homeowners to delay purchases until the inflationary effects of the deduction wear off. See, e.g., Hough, supra note 215 . If potential buyers stay on the sidelines, lower demand would prolong housing market weakness and thus delay triggering the deduction's end. 
for the phase-out serves two purposes. ${ }^{232}$ First, by delaying initiation of the phase-out, Congress can avoid "shocking" the housing market as it only begins to recover from a prolonged slump. ${ }^{233}$ Second, it ensures that the new law will gradually go into effect only after sustained growth occurs rather than on an arbitrary future date. ${ }^{234}$ Although home prices are largely seen to have turned the corner in mid-2012, unforeseen events could trigger another price slide or extremely slow growthphenomena the trigger, but not a nominal date, could react to. ${ }^{235}$

This combined approach to transition-delaying the effective date and gradually phasing out the deduction-is particularly appropriate where Congress is concerned about dramatic transition losses affecting efficiency and fairness, as it should be in eliminating the mortgage interest deduction. ${ }^{236}$ Although

\begin{abstract}
[r]eliance is generally not considered important when a small change is enacted ... . [, a]s the magnitude of the change increases, the potential for significant financial losses also increases, and greater concern is voiced for those who might have altered their behavior to take advantage of the prior law. Delayed or phased-in effective dates may reduce the financial impact of such a change. ${ }^{237}$
\end{abstract}

Beyond being gentler to homeowners and the housing market, this delicate approach does present Congress with certain complications in reforming the tax code. ${ }^{238}$ First, the primary disadvantage of delaying and gradually eliminating the mortgage interest deduction is that it fails to deliver a large infusion of revenue with which to offset lower tax rates

232. See Hearing, supra note 31 (statement of Dr. Richard K. Green).

233. See id. Again, this sensitivity to a particular industry, business, or sector of the economy is not unprecedented. See Bethlehem Steel Corp. v. United States, 270 F.3d 135, 136 (3d Cir. 2001). In 1986, Congress adopted specific language in the Tax Reform Act to ensure domestic steel companies, to which previous law provided investment credits, could "cash out" the repealed credits rather than suddenly lose the value of the credits on their balance sheets. See id.

234. Hearing, supra note 31 (statement of Dr. Richard K. Green). This is conceptually similar to Peter Orzag's proposal to link a temporary payroll tax cut to the unemployment rate. See Peter Orszag, Link U.S. Payroll Tax Holiday to Unemployment Rate, BLOOMBERG (June 30, 2011, 5:55 AM), http://www.bloomberg.com/news/201106-30/payroll-tax-should-be-linked-to-unemployment-rate-peter-orszag.html.

235. Hearing, supra note 31 (statement of Dr. Richard K. Green).

236. See Graetz, supra note 229 , at 87.

237. Id. at 78 n.92.

238. See Logue, supra note 131, at 1130 (noting that in tax reform designed to be at least revenue neutral, limiting "transition relief may be the most obvious way of saving money"). 
or decrease the deficit. ${ }^{239}$ Second, by tying the effective date to a housing market trigger rather than adopting a nominal effective date, Congress would complicate the task of forecasting when even a portion of the revenue from the deduction's elimination would become available. ${ }^{240}$

\section{B. Option 2: Replace the Deduction with a Tax Credit}

\section{Long-Term Advantages and Disadvantages}

There are three advantages to "credifying" tax expenditures such as the mortgage interest deduction: (1) all qualifying homeowners, whether they itemize or not, would receive a benefit for mortgage interest, ${ }^{241}$ (2) the magnitude of the credit's benefit for each taxpayer would be transparent, ${ }^{242}$ and (3) credits provide more progressivity than deductions. ${ }^{243}$ First, a tax credit is a more equitable policy because taxpayers would not be subject to the itemization barrier to claim the benefit, as they are with the deduction. ${ }^{244}$ As previously discussed, more than a quarter of homeowners are ineligible to claim the mortgage interest deduction because their itemized deductions do not exceed the value of the standard deduction. $^{245}$ If Congress reconstituted the deduction as a credit, the benefit could reach lower and middle income, nonitemizing homeowners ${ }^{246}$ and would provide a greater incentive for renters to purchase a home if claiming the benefit were a certainty. ${ }^{247}$ Accordingly, changing the deduction to a credit would address the itemization aspect of the deduction's regressivity. ${ }^{248}$

Second, tax credits provide a more transparent benefit than tax deductions because the benefit's value does not vary by income tax rate. ${ }^{249}$

239. See id. (discussing revenue complications caused by tax reform transition relief); supra note 217 and accompanying text.

240. See Cong. Budget Office, Projecting Federal Tax Revenues and the EFFECT OF CHANGES IN TAX LAW 4 (1998), available at http://www.cbo.gov/sites/default/ files/cbofiles/ftpdocs/10xx/doc1049/taxrev.pdf (discussing the fact that in creating revenue projections for a future year, the Congressional Budget Office assesses whether current law provides that certain itemized deductions will be available in that year).

241. TODER ET AL., supra note 121, at 4.

242. Laurence Seidman, How To Clean Up Tax Expenditures: Terminate or 'Credify,' TAX Notes TodAY, Oct. 12, 2011, available at LEXIS, 2011 TNT 197-8.

243. TODER ET AL., supra note 121, at 5.

244. See id. at 4.

245. See supra text accompanying note 29.

246. MARR \& HighSMITH, supra note 27 , at 6.

247. TODER ET AL., supra note 121, at 4.

248. See MARR \& HigHSMITH, supra note 27, at 7 ("Tax policy ought to lean against the trend of rising inequality, not exacerbate it.”).

249. Seidman, supra note 242. 
Returning to a previous example, ${ }^{250}$ Alice and Ben each purchased homes with \$200,000 mortgages at 5\% interest, resulting in \$10,000 in interest in the first year. Alice received a $\$ 2,800$ tax benefit compared to Ben's $\$ 1,500$ benefit because Alice pays a higher tax rate. Under a mortgage interest credit of 15\%, Alice and Ben would receive the same $\$ 1,500$ tax benefit because the difference in their respective tax rates does not affect the value of the benefit.

Third, because taxpayers with higher incomes would not receive disproportionately larger benefits than those with lower incomes, a mortgage interest credit restores the progressivity the rate structure was designed to achieve. ${ }^{251}$

Despite its advantages over current law, turning the deduction into a credit also has two primary downsides when compared to eliminating the mortgage interest deduction: (1) unless the credit is small, it would fail to substantially broaden the tax base, and (2) it would continue to incentivize housing investment over more productive assets. First, transforming the deduction into a credit would undermine the comprehensiveness of tax simplification and result in less revenue to cut marginal rates or reduce the deficit. ${ }^{252}$ Although replacing the deduction with a 15\% tax credit would provide approximately $\$ 388$ billion over six years $^{253}$ — a not insignificant amount - it would provide far less than complete elimination, which would net between \$879 billion and \$1.26 trillion over ten years. ${ }^{254}$ Second, because it would continue to provide a tax subsidy, a home mortgage interest credit would continue to incentivize investment in housing above other assets. ${ }^{255}$ Relatedly, because the credit would make mortgage subsidies more readily available to current nonitemizers, replacing the deduction with a credit may simply shift the inflationary effect of the deduction from high-priced residences to less expensive homes. ${ }^{256}$

250. See supra text accompanying notes 25-27.

251. See MARR \& HighSMITH, supra note 27, at 5.

252. See CBO's Budget Options Report Includes Tax-Related Analysis, TAX Notes TODAY, Aug. 7, 2009, available at LEXIS, 2009 TNT 150-22.

253. Id. However, this figure represents a policy of changing to a credit while gradually lowering the amount of mortgage debt subject to the $15 \%$ credit from $\$ 1$ million to $\$ 500,000$. Id. Without gradual lowering of the limit, the revenue projection would be larger.

254. TODER ET AL., supra note 121, at 6, 18 tbl.1.

255. See CBO’s Budget Options Report Includes Tax-Related Analysis, supra note 252.

256. JACKSON, supra note 214, at 24. 


\section{Short-Term Consequences}

If Congress replaces the home mortgage interest deduction with a tax credit that continues to provide all current beneficiaries with mortgage interest subsidies, transition losses will be significantly lower than under complete elimination of the deduction. ${ }^{257}$ Like modifying the deduction by lowering the cap, replacing the deduction with a credit would more likely affect high-income earners who could absorb the full cost of interest on their mortgages more readily than lower and middle income homeowners. ${ }^{258}$

\section{Appropriate Transition Relief}

If structured appropriately, changing homeownership subsidies from a deduction to a credit could be a form of permanent transition relief for most homeowners because many would actually see an increase in aftertax income. ${ }^{259}$ For example, replacing the deduction with a refundable credit equal to $17.1 \%$ of home mortgage interest paid would result in net income increases for those in the bottom four income quintiles. ${ }^{260}$ Relatedly, reconstituting the deduction as a credit would primarily increase tax liability for high-income earners. ${ }^{261}$ The overall effect on the housing market would depend on the size of the credit and regional housing costs.

Although the need for transition relief is much less stark in the context of replacing the mortgage interest deduction with a tax credit, Congress could still employ some form of gradual transition relief, such as a phase-in or trigger. ${ }^{262}$ Along those lines, the Congressional Budget Office provided an option to replace the deduction with a 15\% tax credit in 2013 and gradually lower the cap on deductible interest by $\$ 100,000$ increments from $\$ 1$ million in 2013 to a final cap of $\$ 500,000 .^{263}$ Another alternative is to phase in the credit while phasing out the deduction over five years. ${ }^{264}$ For example, in the first year, a taxpayer eligible for the mortgage interest deduction would receive $80 \%$ of the value of the deduction and $20 \%$ of the value of the new credit. ${ }^{265}$ The deduction value would decrease

257. See Mann, supra note 7, at 1393.

258. See Hearing, supra note 31 (statement of Dr. Karl Case); Mathias, supra note 19 , at 74.

259. See TODER ET AL., supra note 121, at 20 tbl.3a.

260. Id.

261. Id. at 10.

262. See CBO’s Budget Options Report Includes Tax-Related Analysis, supra note 252.

263. See id.

264. See Seidman, supra note 242.

265. Id. 
by $20 \%$ each year while the credit value would increase by the same amount until the credit completely eclipses the deduction. ${ }^{266}$ Like other phase-outs, this proposal would provide a gradual change for homeowners and the housing market. ${ }^{267}$

Phasing out the deduction and gradually replacing it with a tax credit could also be paired with Green's housing stability trigger in order to provide an additional layer of transition relief to avoid shocking the real estate market. ${ }^{268}$ A trigger may be problematic, however, if Congress chooses to replace the deduction with a credit because some potential homebuyers might put off buying a home until a credit is available. ${ }^{269}$ For example, a renter looking to buy a home who does not itemize her taxes might wait for the deduction to become a credit before making a purchase. ${ }^{270}$ Accordingly, a triggered credit may keep potential homebuyers on the sidelines and counterproductively prolong housing market ills. ${ }^{271}$ Considering this, and the overall low transition losses gradually replacing the deduction with a credit would cause, Congress should forgo adopting a trigger alongside a credit.

\section{Option 3: Substantially Modify the Deduction}

\section{Long-Run Advantages and Disadvantages}

The last option for changing the mortgage interest deduction is to modify how the deduction works. The modification with the greatest budgetary impact would be to reduce the cap on deductible acquisition debt from its current $\$ 1$ million level. ${ }^{272}$ For example, Senator Tom Coburn proposes decreasing the amount of acquisition debt eligible for the deduction from $\$ 1$ million per couple to $\$ 500,000$ per couple, which would raise approximately $\$ 187$ billion over ten years. ${ }^{273}$ Coburn's

\footnotetext{
266. See id.

267. See supra notes 209-16 and accompanying text.

268. See Hearing, supra note 31 (statement of Dr. Richard K. Green).

269. See Stephanie Armour, Home Sales Fall on Tax Credit Uncertainty, USA ToDAY (Jan. 25, 2010, 11:57 PM), http://www.usatoday.com/money/economy/housing/ 2010-01-25-home-sales_N.htm (demonstrating homebuyers' reactions to the availability and unavailability of tax credits for home consumption).

270. See id.; TODER ET AL., supra note 121, at 19 tbl.2a.

271. See Armour, supra note 269.

272. See Coburn Budget Plan Would Scale Back Mortgage Interest Deduction, supra note 124.

273. Id.
} 
proposal would also limit the deduction to mortgages on a single residence, rather than the two permitted under current law, and would eliminate the deductibility of interest on home equity debt. ${ }^{274}$ Other proposals involve lowering the cap, but adjusting the limit regionally to account for local home prices. ${ }^{275}$

Lowering the cap on the amount of debt eligible for a deduction would address one aspect of regressivity-taxpayers purchasing residences over $\$ 500,000$ would no longer be subsidized for the portion of their mortgage between $\$ 500,000$ and $\$ 1$ million, as current law permits. ${ }^{276}$ However, the primary disadvantage of retaining the mortgage interest subsidy as a deduction is that it would continue to prevent nonitemizing lower and middle income homeowners from benefitting. ${ }^{277}$ Further, although eliminating the deduction for home equity debt would remove a tax incentive to take on nonacquisition debt, a scaled-back deduction would still incentivize overinvestment in housing to the detriment of investment in more productive capital goods. ${ }^{278}$

\section{Short-Term Consequences}

Unlike the consequences of eliminating the home mortgage interest deduction, immediate modification of the deduction would not necessitate dramatic transition relief because it will likely not affect many homeowners. ${ }^{279}$ For example, modifying the deduction by lowering the cap to $\$ 500,000$ would result in fewer transition losses than complete elimination because it would only affect the fewer than $10 \%$ of homeowners whose residences are valued at over $\$ 500,000{ }^{280}$ Lowering the cap on eligible mortgage debt to $\$ 500,000$ would primarily affect regions with high-priced markets, such as San Francisco, but to a lesser extent than

274. Id.

275. See John E. Anderson et al., Capping the Mortgage Interest Deduction, 60 NAT'L TAX J. 769, 770 (2007), available at http://www.stanford.edu/ jclemens/Capping_ the_MID.pdf.

276. See HARDAWAY, supra note 15, at 131.

277. See Lepore, supra note 29 , at $107-08$. The only way to substantially retain the deduction but eliminate the itemization barrier is to make it an "above-the-line" deduction, which would allow all homeowners to claim the deduction regardless of whether their other itemized deductions exceed the standard deduction. See DoDGE, supra note 79, at 14 . The obvious downside to this change is increased cost. See Adam Chodorow, Charitable FSAs: A Proposal To Combine Healthcare and Charitable Giving Tax Provisions, 2011 BYU L. REV. 1041, 1073-74 (discussing the cost of moving a different itemized deduction, the charitable giving deduction, above the line).

278. Hearing, supra note 31 (statement of Dr. Richard K. Green).

279. See 2009 National Home VAlue, supra note 222, at tbl.3-14 (showing that of the 76.4 million housing units in the United States in 2009, only 7.3 million, or just under $10 \%$, were valued at over $\$ 500,000$ ).

280. See id. 
elimination. ${ }^{281}$ Considering the national median home price was under $\$ 250,000$ in $2011,{ }^{282}$ the effects of reducing the limitation would primarily impact those who own expensive homes and would be better able to adjust to changes in home value or taxation. ${ }^{283}$ Those homeowners affected by the reduced cap would still be able to deduct up to $\$ 500,000$ of qualified mortgage debt, again resulting in less transition loss than a complete elimination would produce. ${ }^{284}$

\section{Appropriate Transition Relief}

Nonetheless, to prevent shock to the housing market, Congress could gradually lower the cap and institute a trigger tied to a recovery in home prices. $^{285}$ The Congressional Budget Office, for example, provided a budget option for reducing the deficit by lowering the cap on the deduction by $\$ 100,000$ per year starting in 2013 until it reached $\$ 500,000$ in $2018 .^{286}$ Congress could provide further transition relief by indexing the cap regionally to account for local home prices. ${ }^{287}$

\section{Conclusion: Congress Should Phase Out the Mortgage INTEREST DEDUCTION THROUGH TAX REFORM}

The goal of fundamental tax reform is to encourage economic growth, competitiveness, efficiency, and simplicity. Although eliminating the mortgage interest deduction may be politically unpalatable at first blush, "widespread dissemination of certain facts would make it more palatable to voters," 288 especially when paired with a meaningful cut in tax rates. ${ }^{289}$ The home mortgage interest deduction is costly, ineffective, and economically inefficient, and severely undermines the progressive structure of the American tax system by lavishing its greatest benefits on higher income earners who purchase large homes. Further, by contributing to housing inflation and discouraging Americans from paying down their

281. See Bourassa \& Yin, supra note 180, at 1158.

282. U.S. HOME SALE PRICES, supra note 23.

283. See Mathias, supra note 19, at 74.

284. See Coburn Budget Plan Would Scale Back Mortgage Interest Deduction, supra note 124.

285. See supra notes 209-16, 230-35 and accompanying text.

286. See CBO's Budget Options Report Includes Tax-Related Analysis, supra note 252.

287. See Anderson et al., supra note 275, at 770.

288. HARDAWAY, supra note 15 , at 172.

289. See Steverman, supra note 1. 
mortgage debt, subsidizing housing through the tax code needlessly continues policies that contributed to the housing crisis from which the U.S. economy is still recovering.

By gradually eliminating the deduction over a period of years and not initiating the drawdown of mortgage subsidies until the housing market exhibits sustained growth, Congress can achieve worthy short-run and long-run goals. In the short-term, the housing market will be protected from shock, while current homeowners and incumbent real estate-related businesses that relied on the existence of the deduction can adjust to its elimination gradually. In the long run, investment and housing prices will adjust to market-allocated levels, resulting in more economic productivity and more affordable housing for future generations.

Eliminating the deduction altogether provides important benefits that merely modifying the deduction or replacing it with a credit cannot. Entirely eliminating the deduction provides a maximum infusion of revenue with which to lower marginal tax rates, decrease the budget deficit, provide targeted homeownership assistance, or all of the above. Further, a tax credit or mere modification of the deduction would continue to distort investment in favor of housing rather than more efficient market-allocated investments. Eventual elimination increases economic efficiency and productivity and provides the maximum benefit to the economy and the long-term health of the American housing market. Nevertheless, even if Congress declined to completely eliminate the mortgage interest deduction, turning the deduction into a credit or substantially modifying the deduction would be superior to current law. 